Tierra de minas: de Sierra Mor R Bienes, paisajes e itinerarios 


\section{ena al Valle del Guadalquivir}

El distrito Linares-La Carolina (Jaén) es un territorio marcado por la actividad minera, configurándose en el tiempo un patrimonio cultural rico, heterogéneo y singular, fuente de memoria e identidad. Un legado cuya puesta en valor forma parte de un proceso complejo impulsado por iniciativas ciudadanas, que aglutina a diferentes actores sociales y proyectos de recuperación y uso. Aproximarnos a este patrimonio a través de algunas de las propuestas diseñadas es uno de los objetivos que perseguimos en la sección que inauguramos en este número. 


\section{El valor universal del patrimonio minero-industrial}

Colectivo Proyecto Arrayanes

\section{La propuesta de que el antiguo distrito minero pase a integrar la lista de Patrimonio Mundial se apoya en los criterios de autenticidad e integridad}

Una actividad de relevancia mundial como la minería ha generado en el antiguo distrito minero Linares-La Carolina un patrimonio cultural cuya importancia tiene esa misma dimensión, y que debe ser recuperado tanto para la memoria histórica de la población como para todos aquellos interesados en conocer o estudiar un legado representativo de la que es, probablemente, la industria más antigua de la humanidad. La minería que ha conformado nuestro territorio.

La UNESCO tiene en la actualidad como criterio de actuación favorecer la inclusión de bienes de tipo tecnológico e industrial como patrimonio mundial. Parece, por tanto, que es el momento adecuado para emprender este proceso largo y complejo en cuanto a su tramitación, pero esperanzador e ilusionante para todos los que de una u otra forma nos sentimos integrados en la comarca minera conocida como distrito Linares-La Carolina.

En este sentido, el 9 de junio de 2006, el Colectivo Proyecto Arrayanes (léase p. 85) presentó a los alcaldes de las localidades de Bailén, Baños de la Encina, Carboneros, Guarromán, La Carolina, Linares, Santa Elena y Vilches, el documento de propuesta para la inclusión del antiguo distrito minero LinaresLa Carolina en la lista de nominación como Patrimonio Mundial.

Todos los representantes de estas poblacio nes, que constituían este distrito, apoyaron el documento y acordaron presentarlo para su ratificación en los distintos plenos municipales. El expediente se presentó ante la Delegación Provincial de Cultura de la Junta de Andalucía en ese mismo mes de junio. Actualmente se encuentra en estudio en la Consejería de Cultura, desde donde se decidirá si procede su inclusión y en qué lugar para definir la propuesta que se eleva al Ministerio de Cultura para conseguir la nominación como bienes patrimonio mundial.

El documento de propuesta se ha redactado adaptándolo a los requisitos exigidos por la UNESCO, y destacando especialmente los siguientes criterios de "autenticidad" e "integridad":

\subsection{0 años de historia}

Las últimas investigaciones demuestran que los primeros poblamientos de nuestra comarca tuvieron como finalidad la explotación 


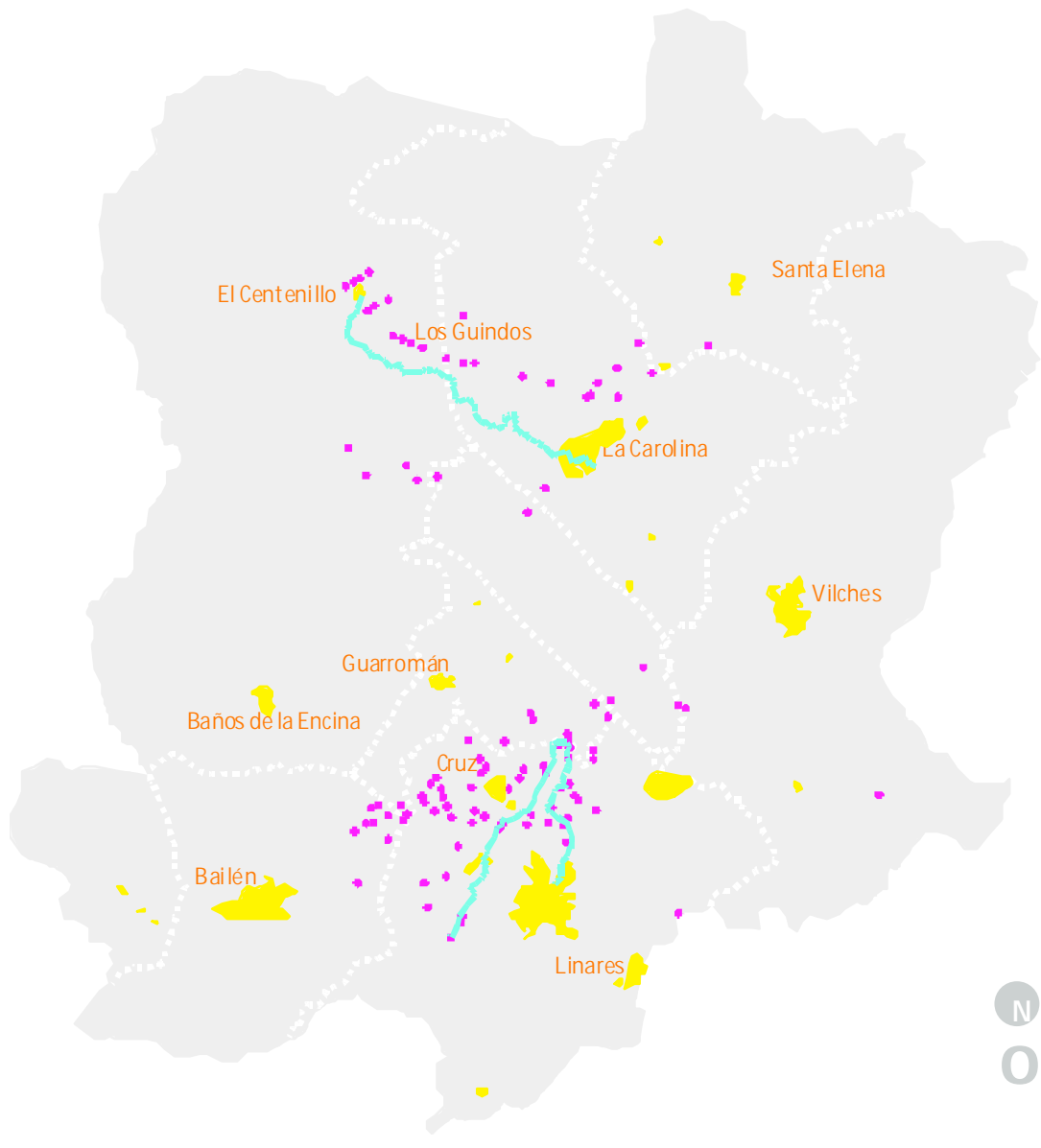

Q Distrito minero LinaresLa Carolina, con los dos recorridos por el territorio que se proponen en esta sección (pp. 92-103) / GeMA Carrera Díaz, David VILLALÓN

minera y metalúrgica, al menos desde la Edad del Bronce. Las grandes potencias de Roma y Cartago se disputaron, en el siglo II y III a.C., el control de los yacimientos de cobre, plata y plomo, que ya habían explotado los íberos. A partir del siglo XVIII, la Hacienda Pública se establece en la mina de Arrayanes, dando un nuevo impulso a una actividad que había decaído durante la Edad Media, pero será en el siglo XIX cuando se produzca el momento de mayor intensidad de la actividad, llegando a convertir al distrito en el principal productor de plomo del mundo. Esta situación se mantuvo hasta después de mediados del siglo XX, disminuyendo desde entonces la producción, hasta que en 1991 cerró la última mina del distrito.

\section{Innovaciones tecnológicas}

Los momentos de más intensa actividad coin ciden con la incorporación que se realiza en el distrito de avances tecnológicos aplicados a la minería. Desde el siglo II a.C., Roma extiende su dominio sobre nuestras minas, y aplica tecnologías de desagüe basadas en las norias, tornillos de Arquímedes y las rudimentarias bombas aspirantes e impelentes de Ctesibio. Con ello los filones pudieron ser explotados

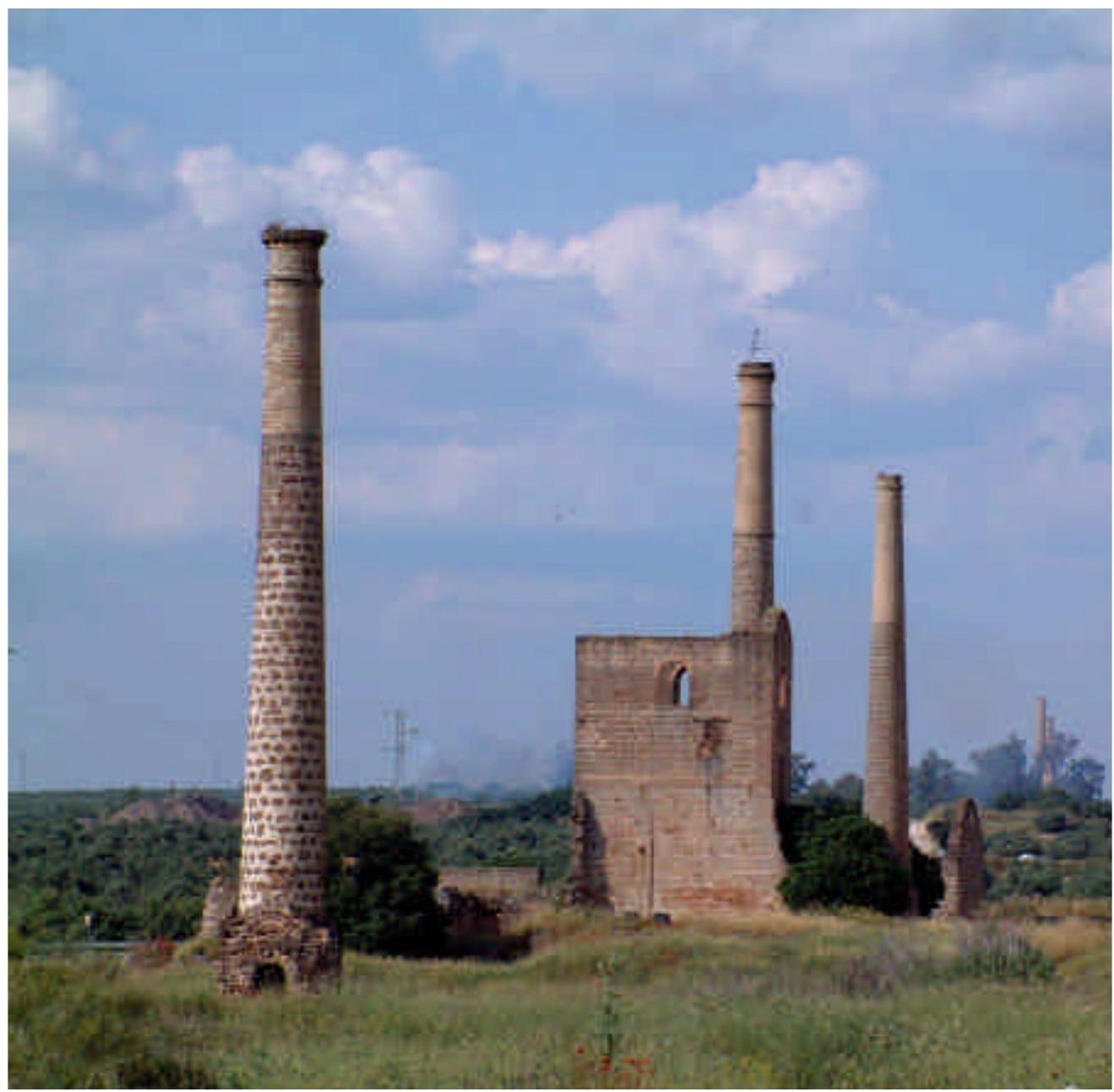




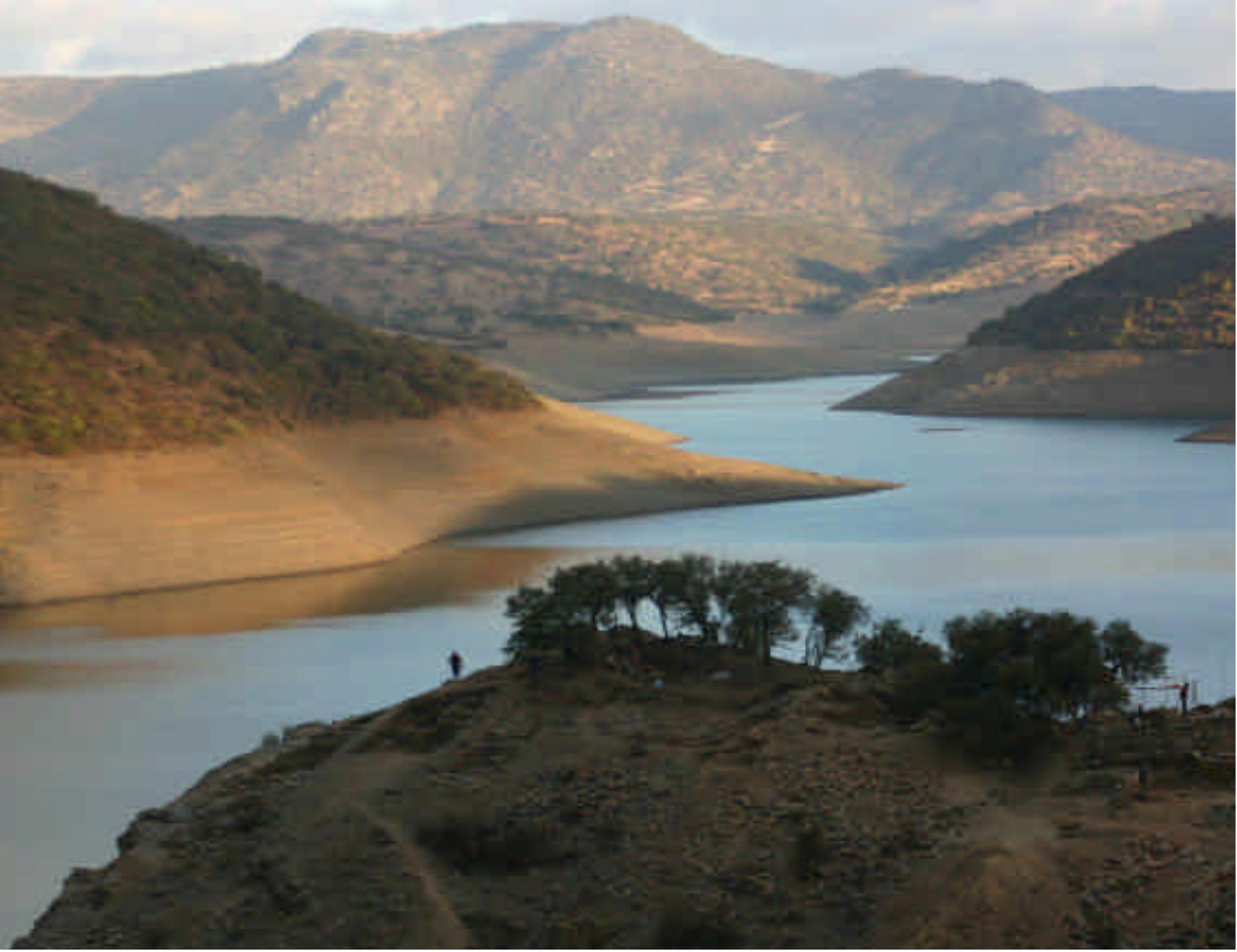

W Yacimiento de la Edad de Bronce en Peñalosa (Baños de la Encina) / Colectrvo Proyecto Arrayanes 
X Pozo de San Vicente. Mina de San Miguel (Linares) / Javier Romero, IAPH

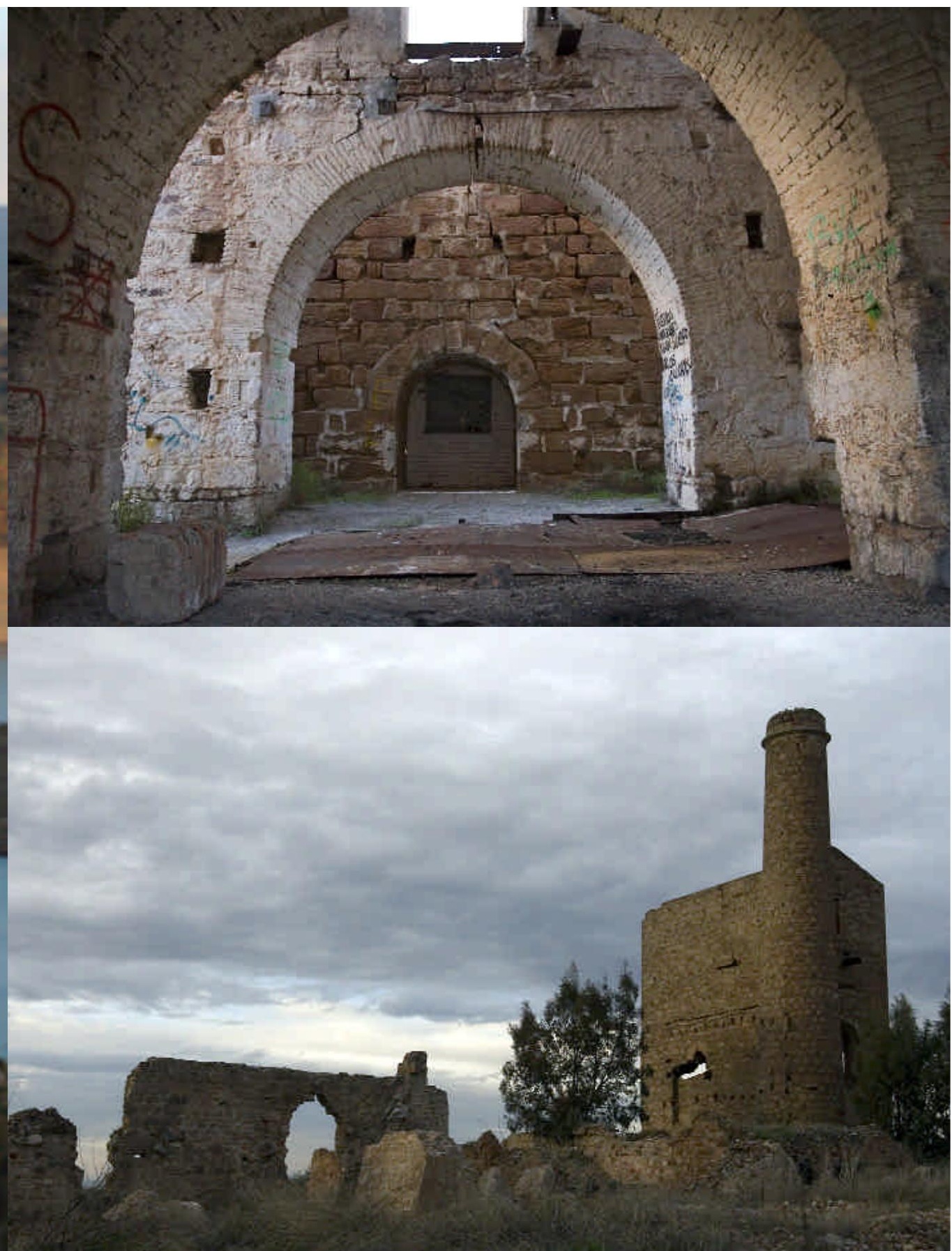

W Pozo San Judas. Mina Pozo Ancho / Javier Romero, IAPH 
X Pozo de Santo Tomás / X Pozo Zulueta. Mina Arrayanes /

Javier Romero, IAPH Colectivo Proyecto Arrayanes

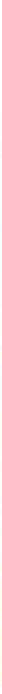

Peculiaridades de la actividad minera como la dependencia mutua en el trabajo, la religiosidad contradictoria o el intercambio cultural, conforman una manera especial de ser, pensar y sentir hasta mayores profundidades. Las minas del distrito fueron descritas por autores clásicos como Plinio y Estrabón. Es a mediados del siglo XIX cuando irrumpe en la comarca minera la tecnología del vapor que proporciona el medio para la explotación más intensiva de los yacimientos. El cambio de la legislación minera, hasta entonces proteccionista, unido a la posibilidad de disponer de los medios tecnológicos más avanzados de la época, permitió la realización de grandes inversiones y el establecimiento de grandes compañías nacionales y extranjeras. Todas ellas configuraron su actividad en base a un modelo que tenía como elemento fundamental la máquina de vapor para el desagüe y para la extracción, que fue traída desde Cornwall a partir de que en 1849 la primera de estas máquinas Cornish demostrara su extraordinaria eficacia en la mina de Pozo Ancho.

La evolución de las poblaciones

La prosperidad económica favorecida por la actividad productiva trajo hasta la zona una enorme cantidad de mineros y trabajadores procedentes de otras regiones españolas y de países europeos. Esto supuso un fuerte crecimiento demográfico, a un ritmo muy acelerado, que requirió actuaciones de desarrollo urbanístico muy urgentes y de gran calado, que a duras penas consi- guieron resolver los problemas de hacinamientos y demandas de servicios esenciales de las poblaciones mineras.

En un primer momento fue la zona de Linares la que soportó un incremento de 7000 a 40000 habitantes en unos 30 años. Para hacer frente a este crecimiento se elaboró un plan de ensanche, que sólo pudo ser desarrollado parcialmente, y crecieron en la ciudad barriadas mineras así como poblados en las principales instalaciones más alejadas de las ciudades. A finales del siglo XIX, la mayor actividad en la zona de La Carolina ocasionó un proceso similar que aceleró el crecimiento de una ciudad planificada inicialmente como capital de las nuevas poblaciones.

Acudieron a la zona los grandes bancos, industrias auxiliares, se construyeron infraestructuras de servicios y comunicación, destacando la gran red de ferrocarriles de vía estrecha y de ancho normal, lo que confirió a las poblaciones un dinamismo y una estructura que ha permitido su desarrollo industrial, social y cultural.

\section{Configuración de un paisaje cultural}

La relación que los seres humanos han establecido con el territorio a lo largo de la historia de la minería ha ido configurando un paisaje cultural en el que se conservan huellas de la 
X Vista de la Mina El Mimbre /

Colectivo Proyecto Arrayanes

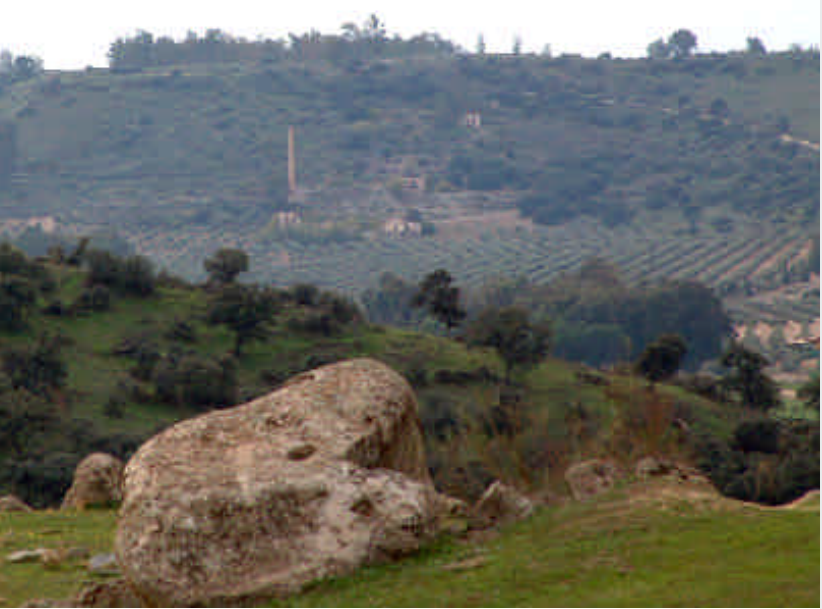

actividad extractiva, así como de otras actividades humanas asociadas a sus poblaciones Así podemos encontrar rafas y trincheras de trabajos antiguos, frecuentes en la zona de Paño Pico y Sierra Morena; escombreras y escoriales como restos de la explotación o de las actividades metalúrgicas; diques de estériles, algunos de ellos recolonizados por la fauna y flora autóctonas; agrupamientos de eucaliptos, que señalan la presencia de las minas, así como restos de edificaciones de diversos tipos asociadas a la actividad minera que se han convertido para la población en iconos y símbolos que identifican el paisaje.

\section{Aspectos de la cultura minera}

La población del distrito ha disfrutado los momentos de éxito y ha padecido los fracasos de la actividad minera desde siempre, lo que ha dado lugar a unas intensas señas de identidad que van más allá de las expresiones culturales tangibles y conforman una manera de ser, de pensar y de sentir. Esto ha ido configurando un tipo de estructura social y de organización del trabajo característicos que determinaron los sistemas de contratación y de relación laboral, la organización de los tajos y la dependencia mutua en el trabajo, generando sistemas muy distintos a los propios de la sociedad agrícola circundante. Asimismo aparecieron en época temprana movimientos

\section{Una sociedad industrial al norte de Andalucía}

El distrito minero Linares-La Carolina está situado al norte de Jaén, por lo tanto en la zona más al norte de Andalucía. Su clima es, por esta razón, más extremo que el litoral, con inviernos fríos y veranos extremadamente calurosos y secos. Ocupa un área de $40 \mathrm{~km}$, que se extiende desde Despeñaperros (en Sierra Morena) hacia el sur, con una anchura de este a oeste de $30 \mathrm{~km}$ aproximadamente. La altitud con respecto al nivel del mar está comprendida entre los 300 y los 825 metros.

Incluye territorio perteneciente a ocho municipios: Linares, Bailén, Baños de la Encina, Guarromán, Vilches, Carboneros, La Carolina y Santa Elena. Se divide, portanto, en dos zonas bien diferenciadas. Por un lado, las suaves estribaciones de Sierra Morena situadas en el sureste $y$, por otro lado, la zona montañosa del noroeste.

Podría parecer una tierra inhóspita, pero su riqueza mineral la ha convertido en un lugar de gran valor, cuya explotación se han disputado distintas potencias mundiales a lo largo de la historia y ha sido objeto de diferentes colonizaciones, recibiendo e incorporado a su población emigrantes procedentes de lugares lejanos en todas las épocas históricas.

Otra de las características esenciales de esta comarca es la de haber constituido un enclave industrial de gran importancia, que se ha convertido desde mediados del siglo XIX en una llamativa excepción de la realidad socioeconómica andaluza, situada dentro de un entorno provincial y comarcal casi exclusivamente dedicado a la agricultura.

El enorme desarrollo alcanzado por la minería generó una sociedad con acusadas características industriales, que tuvo que desarrollar y adaptar su crecimiento urbano, mediante planes de ensanche, a las grandes exigencias de mano de obra; una sociedad en la que se establecieron grandes compañías extranjeras y nacionales, que contó con un gran número de industrias auxiliares y entidades bancarias, a la que llegaron con adelanto la red ferroviaria, la electrificación y el tranvía y en la que, en suma, se vivieron con intensidad las grandes convulsiones sociales del siglo XIX.

Y así continuó hasta 1991, cuando la economía del distrito, tras largos e intensos conflictos sociales y laborales, tuvo que encajar el durísimo golpe del cierre de la última mina y el abandono de esta actividad que fue el origen de los primeros asentamientos en la zona. Rápidamente una población que había vivido durante más de siglo y medio los éxitos y fracasos de la minería concentró sus esfuerzos en el desarollo de otras actividades industriales. 


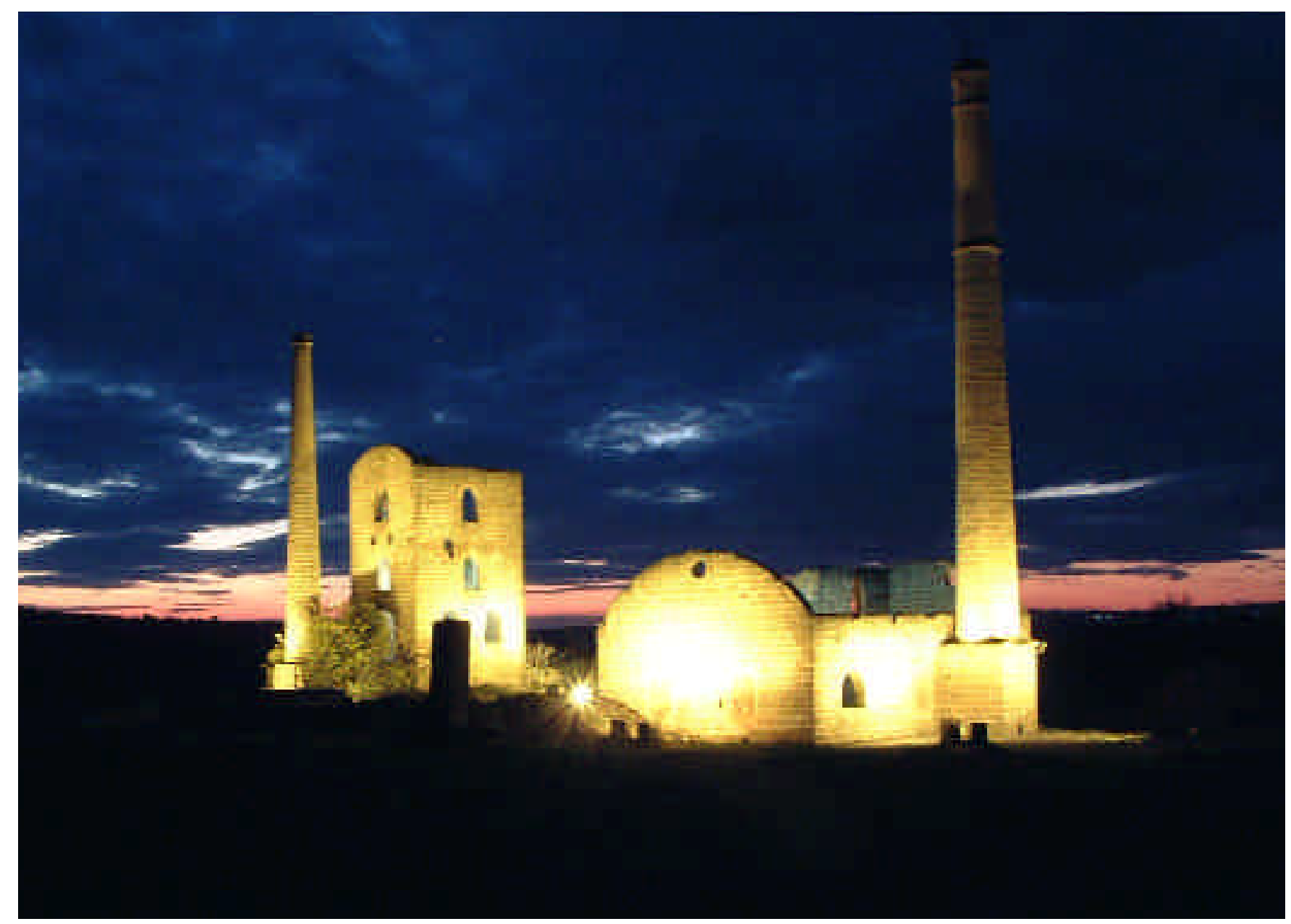

W Los Lores iluminado. Minas de la Tortilla / Colectivo Proyecto Arrayanes

\section{Alrededor de un \\ centenar de \\ chimeneas señalan la \\ situación de minas 0 \\ fundiciones y se han \\ convertido en iconos \\ que identifican un \\ paisaje cultural}

obreros que, de forma más o menos organizada, defendieron los intereses de los trabajadores y un gran número de publicaciones periódi cas de carácter político y social.

La forma de percibir la religión y de integrarla en las costumbres, tanto en la vida personal como en el ámbito colectivo, fue también muy característica. Respondía a los patrones de comportamiento del minero, ciertamente contradictorios. Por un lado, el abandono a la providencia, característico de quien acostumbra a arriesgar la vida, y el orgullo de la participación en eventos religiosos como la Semana Santa.

Nuestro territorio ha acogido siempre a personas provenientes de otros lugares, de ahí que las costumbres se hayan ido configurando como el resultado de un intercambio cultural permanente entre inmigrantes procedentes de muy diversos lugares que, lejos de aislarse y constituir pequeñas comunidades, se han mezclado y han compartido sus modos de vida a la par que la dureza de su trabajo.

La convivencia con mineros y obreros especializados procedentes de otros países ha dejado testimonios materiales, entre los que sobresale el campo de fútbol de El Centenillo o el cementerio "inglés" en Linares, que aún pervive junto al cementerio católico y en el que se conservan en muy buen estado tumbas de mineros, técnicos y obreros extranjeros.

\section{La arquitectura industrial}

El conjunto de edificaciones mineras constituye un ejemplo único y muy completo de arquitectura industrial, que convive con yacimientos de explotaciones mineras y de asentamientos de otras épocas de la historia, combinando el valor arquitectónico y tecnológico y el de un paisaje que ilustra los estados significativos de la historia humana. El distrito tiene la mayor concentración de restos arquitectónicos mineros de tipología Cornish que se puede encontrar en el mundo a excepción de Inglaterra. Además, algunos de ellos son ejemplos singulares de varias tipologías arquitectónicas relacionadas con las instalaciones mineras. Se conservan 32 casas de máquinas de bombeo de tipo Cornish; más de 70 casas de máquinas de extracción; una cantidad similar de restos de casas para alojar las calderas, de las que una docena se conserva 


\section{Más de cien inmuebles incoados}

El 16 de octubre de 2006, la Dirección General de Bienes Culturales incoó expediente de protección de sesenta inmuebles del patrimonio minero industrial localizados en el antiguo distrito Linares-La Carolina, con el objetivo de inscribirlos como genérica colectiva en el Catálogo General de Patrimonio Histórico Andaluz, complementando así la incoación realizada en 2003 (resolución de 3 de diciembre, BOJA № 8 de 14 de enero de 2004) de otros sesenta y cinco inmuebles, todos ellos pertenecientes a dicho distrito (ver cuadros $p .76$ y p.81)

La incoación de expedientes de protección del patrimonio minero industrial del antiguo distrito de Linares-La Carolina responde a una de las líneas desarrolladas por el Servicio de Protección del Patrimonio Histórico que consiste en el reconocimiento de los valores culturales que residen en los bienes de esta tipología. Valores de carácter histórico, social, técnico, científico, paisajístico e incluso en algunos casos arqueológico, dado que el conjunto de estos inmuebles es el reflejo de las formas de vida y de trabajo de determinadas identidades colectivas, de unas formas de organización del territorio y de una evolución paisajística propia marcada por la actividad allí desarrollada a lo largo del tiempo.

La concentración histórica de inmuebles relacionados con esta actividad minera que se observa en el antiguo distrito de Linares-La Carolina puede ser una de las mayores de Europa. Los restos, desde edificios a instalaciones complejas compuestas de casas de máquinas de bombeo, extracción, calderas, lavaderos, chimeneas, cabrias, cables aéreos y tolvas, entre otras estructuras, así como la gran variedad de maquinaria empleada para las labores de extracción, tratamiento, transporte, etc., permanecen como testimonio de la tecnología utilizada y son reflejo del complejo mundo desarrollado en la zona.

Además de estas instalaciones especializadas también se encuentran varios pobla dos mineros, algunos de ellos actualmente habitados y cuyas estructuras han sido reformadas para adaptarlas a las funciones que en ellas se realizan, mientras que otros han sido completamente abandonados.

Como ejemplo del primero de los casos tenemos el poblado de Los Guindos, ubicado en los términos de La Carolina y Baños de la Encina. Este inmueble incluye un conjunto de viviendas e instalaciones mineras localizadas en torno a los caminos de acceso a los pozos El Guindo y La Manzana. Las viviendas conservan parte de su tipología original aunque en esencia han sido rehabilitadas para mantenerlas en uso. También encontramos complejos como La Culebrina, en Baños de la Encina, formado por varios edificios mineros entre los que destaca una casa de máquina de bombeo Cornish, una casa de máquinas de extracción y otras de generadores, calde ras y transformación. Del poblado, de reducidas dimensiones, se conservan viviendas de trabajadores e ingenieros. Por otro lado, el ejemplo más claro del segundo de los casos es el del poblado denominado El Sinapismo, en La Carolina, en este momento deshabitado, aunque mantiene el trazado de las calles, así como algunas viviendas e instalaciones industriales.

Toda esta actividad minera y las instalaciones que conlleva conducen a la creación de un paisaje singular que caracteriza e identifica esta comarca diferenciándola de otras. Con el abandono de los establecimientos mineros y el cese de la actividad, que culmina en 1991, año en el que cierra la Compañía de Minas La Cruz, última empresa minera del distrito, aumenta el deterioro de toda esta infraestructura con el consiguiente peligro de desaparición y pérdida de valores y bienes. 


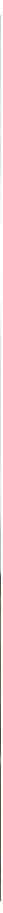

Para la puesta en

valor de este legado es decisivo

que la sociedad

local lo integre

como algo propio

y lo defienda como

signo inequívoco

de identidad en buen estado; alrededor de un centenar de chimeneas que señalan inequívocamente la situación de minas o fundiciones; un ejemplar único de casa de máquina de bombeo de acción directa, tipo Bull, que puede ser una de las tres que queden en pie; cerca de una veintena de cabrias metálicas, así como un número equivalente de cabrias de mampostería que son características del distrito; lavaderos de mineral que aprovechaban los desniveles del terreno para separar la galena; una decena de restos de fundiciones en las que se obtenía el plomo, destacando los cuatro ejemplares de torres de perdigones que pueden suponer la quinta parte de todas las que quedan en el mundo.

Una actividad industrial tan importante y diseminada por el territorio generó a su vez un com plejo sistema compuesto por diferentes elementos de comunicación y transporte: una densa red de caminos que conectaban las instalaciones mineras entre sí y con las distintas poblaciones, tanto de titularidad pública como propiedad de algunas compañías; trazado férreo de vía estrecha que unía las dos principales zonas de explotación minera; la línea Linares-Los Salidos que circundaba la zona norte alrededor de Linares conectando importantes minas; conexiones con la red regional y nacional para traer combustibles y dar salida a la producción, así como varios ferrocarriles mineros que formaban parte de las infraestructuras propias de las grandes compañías; cuatro líneas de cable aéreo que salvaban zonas de difícil orografía, permitiendo el abastecimiento y el transporte de mineral hasta los terminales de carga cercanos a las vías férreas.

Como conclusión, consideramos que nuestro patrimonio presenta unas características muy adecuadas para lograr el objetivo de su declaración. Si lo comparamos con otros lugares de patrimonio minero ya declarados patrimonio mundial, encontramos que:

j En la lista de lugares y emplazamientos mineros declarados no hay ninguno que abarque tantas épocas de la historia: 4000 años (Edad del Bronce, época romana, medieval e industrial).

j No se ha declarado aún ningún lugar de minería del plomo, ya que sólo en Rammelsberg (Alemania) la actividad extractiva se dedicaba parcialmente a este metal. 
X Paisaje marcado por la actividad minera en la zona de La Carolina / Javier Romero, IAPH

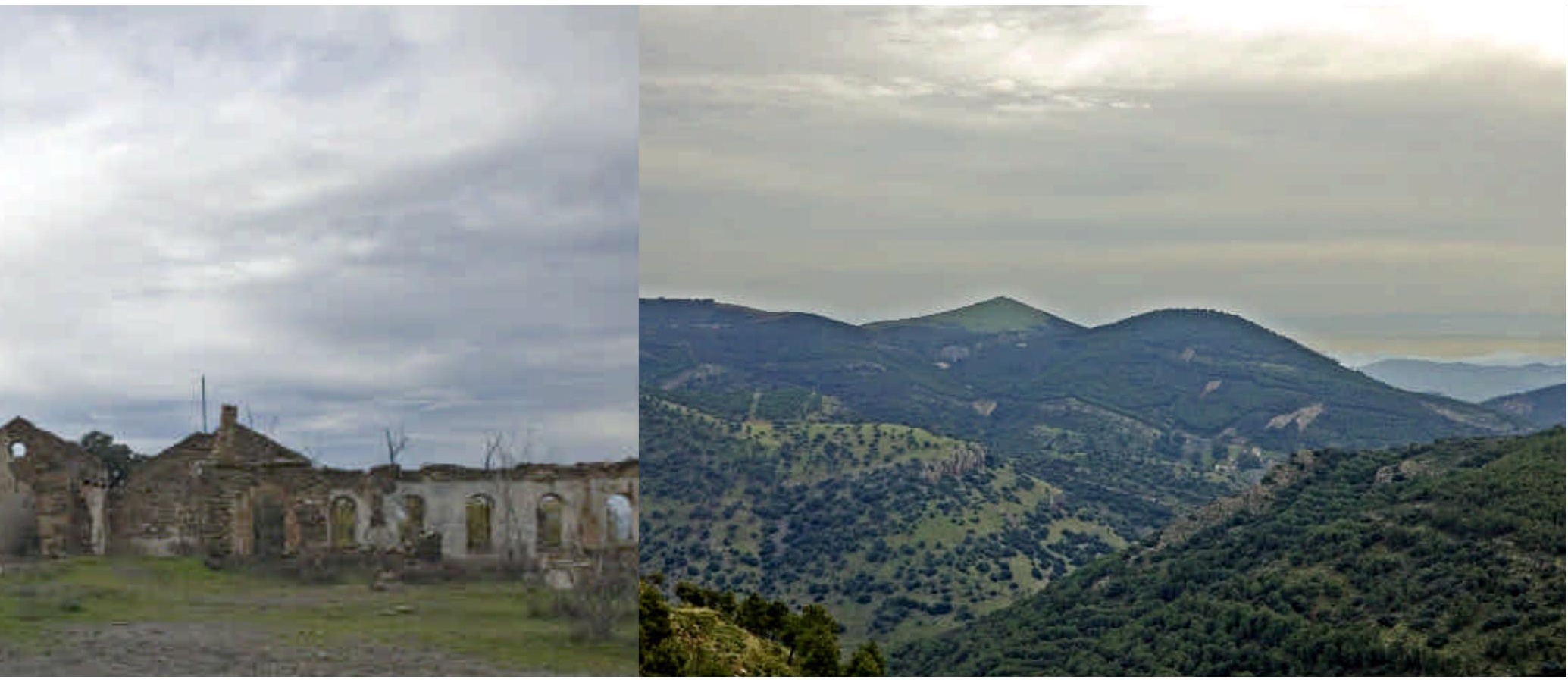

j En España sólo Las Médulas ha sido declarado patrimonio mundial y es representativo de una época de la minería, la romana.

Distintos visitantes, tanto de nuestro país como de diferentes países europeos, han reconocido los enormes valores del legado que la minería nos ha dejado a lo largo del tiempo. Sin embargo, y siendo muy importante el reconocimiento ajeno, es mucho más decisivo para su puesta en valor que la sociedad local lo integre como algo propio, lo defienda como un signo inequívoco de identidad y contribuya en la mayor medida a incrementar sus valores.

Debemos tener claro que conseguir la declaración como patrimonio mundial no es el fin, sino un medio para seguir avanzando, un sello que garantice la calidad del desarrollo cultural y socioeconómico que se vaya realizando. Pero para conseguirla tendremos que demostrar la bondad de las actuaciones previas y el compromiso de continuar trabajando en esta línea, con planes de gestión bien diseñados, con nuevas actuaciones coherentes y con unos objetivos que en sí mismos se proyectan hacia el futuro.

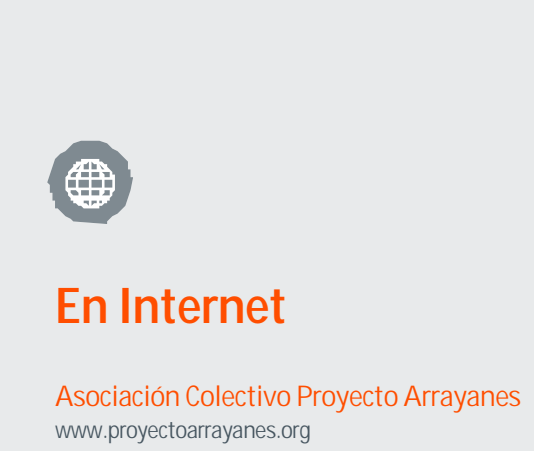

El Proyecto Arrayanes es una propuesta de protección, conservación, recuperación y puesta en valor del patrimonio minero industrial del distrito minero Linares-La Carolina. La página web incluye, además de una referencia a la propia asociación y su proyecto, amplia información sobre el distrito minero Linares-La Carolina desde el punto de vista histórico y patrimonial (incluido el catálogo de los bienes protegidos), las técnicas de extracción minera, el paisaje y el territorio, entre otros aspectos.

\section{Ayuntamiento de Linares}

www.ayuntamientodelinares.org/linares/ruta_minera.htm

www.ayuntamientodelinares.org/linares/minas_en_linares.htm

Se trata de dos accesos, "Ruta minera" y "Minas en Linares", dependientes de la web del Ayuntamiento de Linares y en los que en definitiva se describe una ruta para conocer el paisaje minero de la zona. 
Inmuebles con inscripción genérica colectiva en el Catálogo General de Patrimonio Histórico por Resolución de 3 de diciembre de 2003 (BOJA no 8, 14 enero de 2004)

\begin{tabular}{|c|c|c|}
\hline Denominación & Municipio & Tipol ogías \\
\hline Pozo núm. 1 (Ba-04) & Bailén & Pozos mineros \\
\hline Pozo San José- Matacabras (Ba-05) & Bailén & Pozos mineros \\
\hline Pozo El Correo (Ba-01) & Bailén & Pozos mineros \\
\hline La Esmeralda & Bailén & Edificios industriales \\
\hline Pozo no 3 (Ba-03) & Bailén & Pozos mineros \\
\hline Pozo no 3 (Ba-06) & Bailén & Pozos mineros \\
\hline San Diego (Ba-07) & Bailén & Pozos mineros \\
\hline Pozo no 5 (Ba-08) & Bailén & Pozos mineros \\
\hline San Luis (Gu-01) & Guarromán & Pozos mineros \\
\hline San Cayetano (Gu-02) & Guarromán & Pozos mineros \\
\hline Pozo no 3 (Gu-03) & Guarromán & Pozos mineros \\
\hline San Andrés (Gu-04) & Guarromán & Pozos mineros \\
\hline El Calvario (Li-19) & Linares & Pozos mineros \\
\hline Victoria (Li-01) & Linares & Pozos mineros \\
\hline Santa Annie (Li-02) & Linares & Pozos mineros \\
\hline San Federico (Li-03) & Linares & Pozos mineros \\
\hline Pozo no $0($ Li-20) & Linares & Pozos mineros \\
\hline Lavadero (Li-21) & Linares & Pozos mineros \\
\hline El Fin (Li-04) & Linares & Pozos mineros \\
\hline San José (Li-05) & Linares & Pozos mineros \\
\hline Barings (Li-06) & Linares & Pozos mineros \\
\hline San Adriano (Li-07) & Linares & Pozos mineros \\
\hline San Ignacio (LI-22) & Linares & Pozos mineros \\
\hline Zulueta (Li-23) & Linares & Pozos mineros \\
\hline San Enrique (Li-08) & Linares & Pozos mineros \\
\hline La Unión (Li-24) & Linares & Complejos extractivos \\
\hline Las Cadenas (Li-25) & Linares & Pozos mineros \\
\hline El Chaves (Li-26) & Linares & Pozos mineros \\
\hline San Francisco (Li-09) & Linares & Pozos mineros \\
\hline San Rafael (Li-27) & Linares & Pozos mineros \\
\hline San Judas (Li-10) & Linares & Pozos mineros \\
\hline Juanita (Li-28) & Linares & Pozos mineros \\
\hline Santo Tomás (Li-11) & Linares & Pozos mineros \\
\hline Acosta (Li-12) & Linares & Pozos mineros \\
\hline Restauración (Li-13) & Linares & Pozos mineros \\
\hline San José (Li-14) & Linares & Pozos mineros \\
\hline Magdalena (Li-29) & Linares & Pozos mineros \\
\hline Central Eléctrica (Li-15) & Linares & Centrales eléctricas \\
\hline San Guillermo (Li-16) & Linares & Pozos mineros \\
\hline Pozo Rico (Li-17) & Linares & Pozos mineros \\
\hline San Pablo (Li-30) & Linares & Pozos mineros \\
\hline San Vicente (Li-18) & Linares & Pozos mineros \\
\hline Santa Margarita (Li-31) & Linares & Pozos mineros \\
\hline Rivero (Li-32) & Linares & Pozos mineros \\
\hline Las Animas & Linares & Pozos mineros \\
\hline San Isidro 10 y 20 (Li-34) & Linares & Pozos mineros \\
\hline San Francisco 2a (Li-35) & Linares & Pozos mineros \\
\hline Santa Teresa (Li-36) & Linares & Pozos mineros \\
\hline Los Ministros (Li-37) & Linares & Pozos mineros \\
\hline Pozo B (Li-38) & Linares & Pozos mineros \\
\hline Linarejos (Li-39) & Linares & Pozos mineros \\
\hline Reina $(\mathrm{Li}-40)$ & Linares & Pozos mineros \\
\hline Línea de Ferrocarril Linares Los Sa (Li-Fer-04) & Linares & Edificios del transporte \\
\hline Estación de Madrid (Li-Fer-01) & Linares & Estaciones (Transporte) \\
\hline Fundición La Tortilla (Li-Met-01) & Linares & Fundiciones \\
\hline Torre de Perdigones La Tortilla (Lit-Met-02) & Linares & Torres \\
\hline Chimeneas La Tortilla (Li-Met-03) & Linares & Chimeneas \\
\hline Estación Pozo Ancho (Li-Fer-03) & Linares & Estaciones (Transporte) \\
\hline Chimeneas La Esperanza (Li-Met-04) & Linares & Chimeneas \\
\hline Fundición San Luis (Li-Met-08) & Linares & Fundiciones \\
\hline Chimeneas Fundición A. Hidalgo (Li-Met-05) & Linares & Chimeneas \\
\hline Fundición La Constancia (Li-Met-09) & Linares & Fundiciones \\
\hline Torre Perdigones La Cruz & Linares & Torres \\
\hline Chimenea La Cruz (Li-Met-07) & Linares & Chimeneas \\
\hline
\end{tabular}




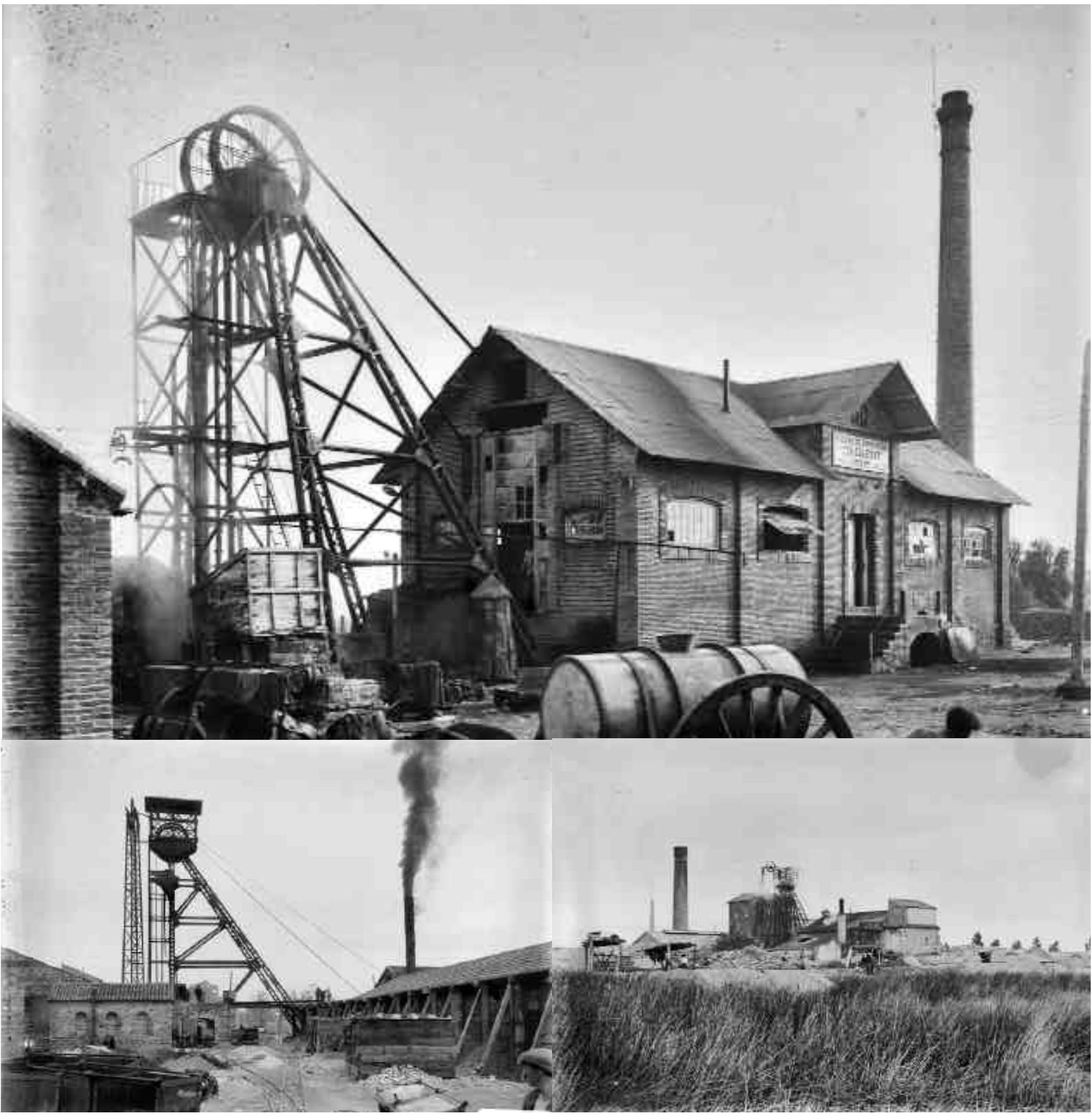

W Pozo Acosta (Linares) / Lucien Roisin Besnard. Institut d’Estudis Fotogràitcs de Catalunya. Col. Roisin

W Pozo San José (Linares) / Lucien Roisin Besnard. Institut d'Estudis Fotogràtics de Catalunya. Col. Roisin 


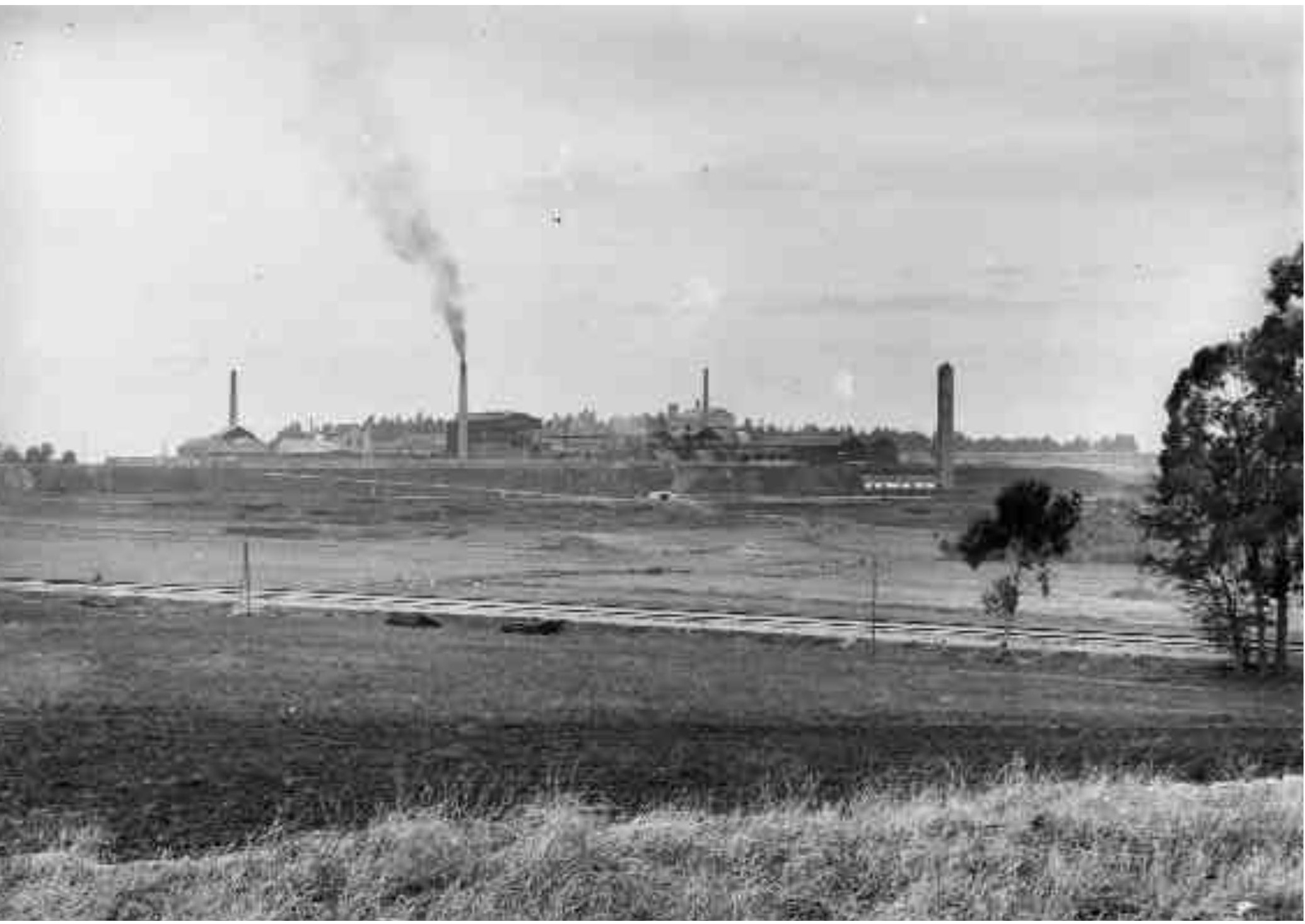

W Línea de ferrocarril con la Fundición de La Cruz al fondo / Lucien Roisin Besnard.

InSTITUT d'Estudis Fotogràfics DE

Catalunya. Col. Roisin 


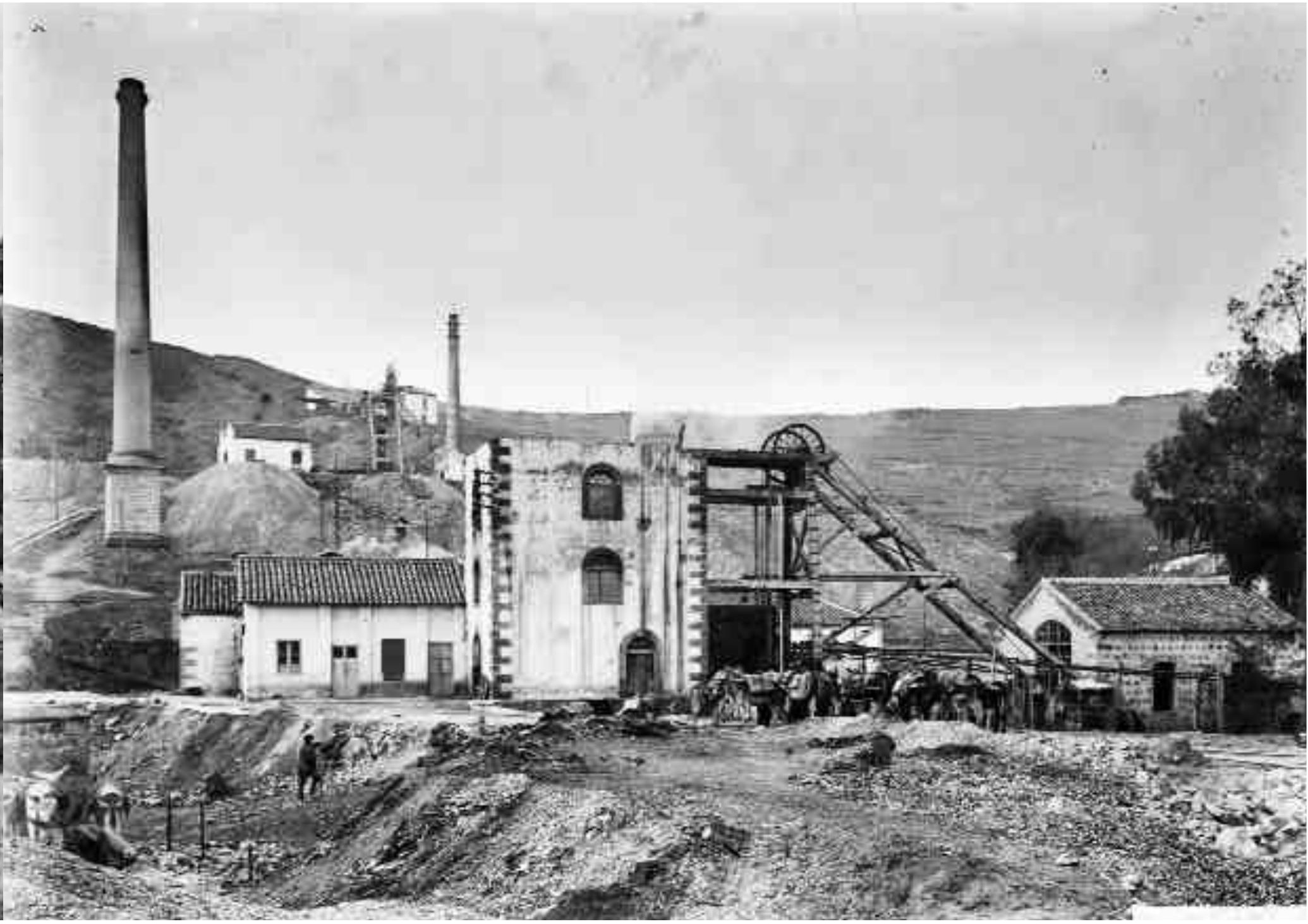

W Pozos de la Mina El Mimbre / Lucies

Roisin Besnard. Institut d'Estudis

Fotogràfics de Catalunya. Col. Roisin 


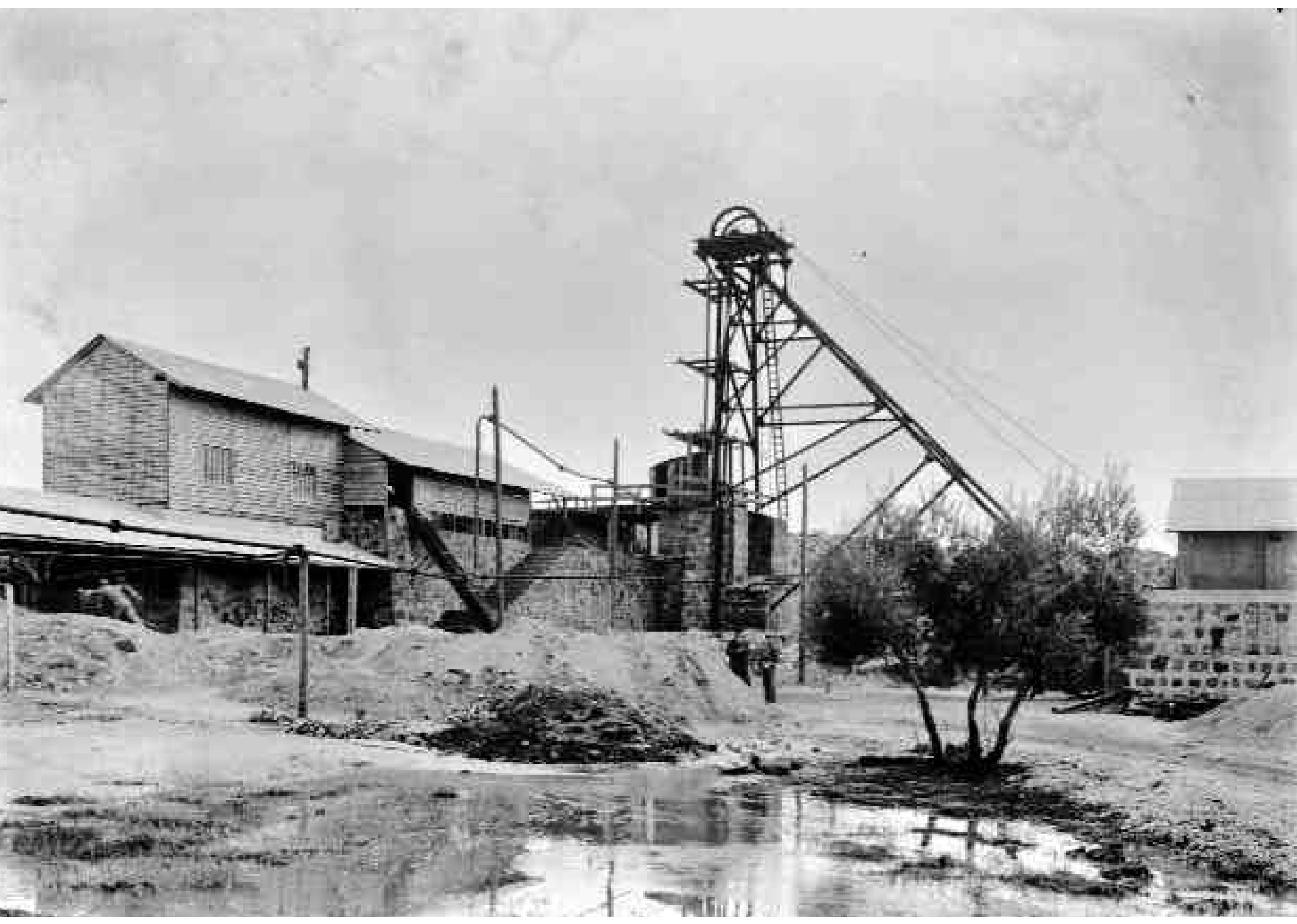

W Minas de la Cruz (Linares) / Lucien

Roisin Besnard. Institut d’Estudis

Fotogràfics de Catalunya. Col. Roisin 
Inmuebles con Incoación genérica colectiva en el Catálogo

General de Patrimonio Histórico por Resolución de 16 de octubre de 2006 (BOJA nㅇ219, 13 de noviembre de 2006)

Den o min a ción
Briones
Araceli
Pozo Nuevo
El Mirador
Santo Tomás
El Águila
El Macho
San Guillermo
La Botella
La Culebrina
Los Curas
El Soldado
La Reforma
Monteponi
San Agustín
El Manto
Palazuelos
San Eugenio
La Jaula
Estación de Descarga de Cable
Aquisgrana
Lavadero de Aquisgrana
Pozo Federico
Poblado El Sinapismo
Torre de Perdigones I
Torre de Perdigones II
La Rosa
La Makrina
La Inmediata
San Guillermo
La Española Guindos
Casa de Central en La Urbana
Poblado Los Guindos
Socavón y Lavadero La Manzana
Socavón Santa Juana
San Telmo
San Simón
San Pascual
San Arturo
Pozo Chimenea
San Blas
La Mejicana
Carmen
Herrera
La Memoria
Mistero
María Linarejos
Venus
Lavadero de Adaro
Las Encantadoras
La llusión
Pozo Paquita
Socavón
Santo Rostro
Santa María
Lavadero Vimora
San Gabriel
El Alcázar
La Española
San Miguel

Sal

\section{Municipio \\ Bailén}

Baños de la Encina Baños de la Encina

Baños de la Encina

Baños de la Encina

Baños de la Encina

Baños de la Encina

Baños de la Encina

Baños de la Encina

Baños de la Encina

Baños de la Encina

Baños de la Encina

Baños de la Encina

Baños de la Encina

Baños de la Encina

Baños de la Encina

Carboneros

Carboneros

Carboneros

Carboneros

Carolina, La

Carolina, La

Carolina, La

Carolina, La

Carolina, La

Carolina, La

Carolina, La

Carolina, La

Carolina, La

Carolina, La

Carolina, La

Carolina, La

Carolina, La

Carolina, La

Carolina, La

Carolina, La

Guarromán

Guarromán

Guarromán

Guarromán

Guarromán

Linares

Linares

Linares

Linares

Linares

Linares

Linares

Linares

Linares

Linares

Linares

Linares

Linares

Linares

Linares

Santa Elena

Vilches

Vilches

Vilches

\section{Tipol ogías}

Pozos mineros

Complejos extractivos Complejos extractivos Complejos extractivos Complejos extractivos Complejos extractivos Complejos extractivos Complejos extractivos Complejos extractivos Complejos extractivos Complejos extractivos Complejos extractivos Complejos extractivos Complejos extractivos Pozos mineros

Complejos extractivos Complejos extractivos Complejos extractivos Complejos extractivos Complejos extractivos Complejos extractivos Lavaderos de mineral Pozos mineros

Poblados

Torres

Torres

Complejos extractivos Complejos extractivos Complejos extractivos Complejos extractivos Complejos extractivos Centrales eléctricas Poblados

Lavaderos de mineral Túneles

Complejos extractivos Complejos extractivos Complejos extractivos Complejos extractivos Pozos mineros Complejos extractivos Chimeneas

Complejos extractivos Complejos extractivos Complejos extractivos Almacenes

Complejos extractivos Complejos extractivos Lavaderos de mineral Pozos mineros Complejos extractivos Pozos mineros Túneles

Pozos mineros

Complejos extractivos Lavaderos de mineral Complejos extractivos Complejos extractivos Complejos extractivos Complejos extractivos 
X Vista de la Mina El Mimbre /

Colectivo Proyecto Arrayanes

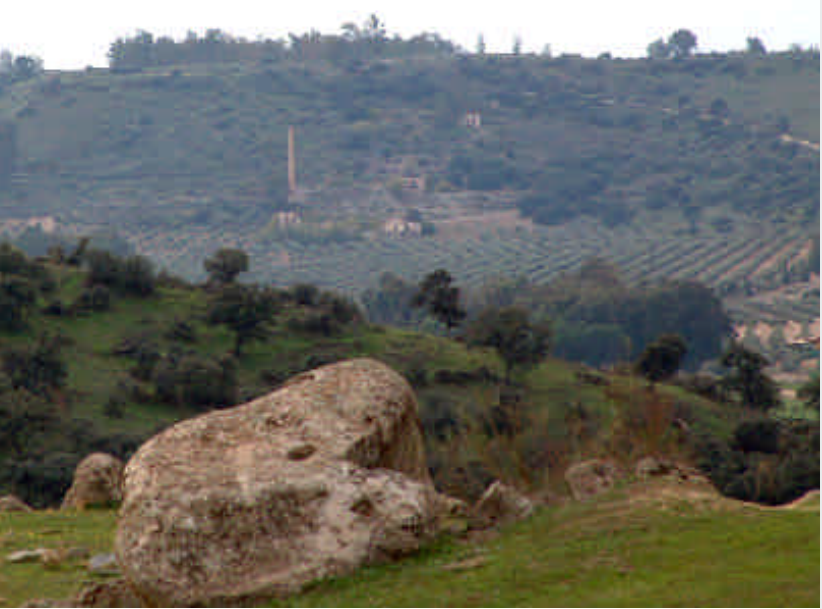

actividad extractiva, así como de otras actividades humanas asociadas a sus poblaciones Así podemos encontrar rafas y trincheras de trabajos antiguos, frecuentes en la zona de Paño Pico y Sierra Morena; escombreras y escoriales como restos de la explotación o de las actividades metalúrgicas; diques de estériles, algunos de ellos recolonizados por la fauna y flora autóctonas; agrupamientos de eucaliptos, que señalan la presencia de las minas, así como restos de edificaciones de diversos tipos asociadas a la actividad minera que se han convertido para la población en iconos y símbolos que identifican el paisaje.

\section{Aspectos de la cultura minera}

La población del distrito ha disfrutado los momentos de éxito y ha padecido los fracasos de la actividad minera desde siempre, lo que ha dado lugar a unas intensas señas de identidad que van más allá de las expresiones culturales tangibles y conforman una manera de ser, de pensar y de sentir. Esto ha ido configurando un tipo de estructura social y de organización del trabajo característicos que determinaron los sistemas de contratación y de relación laboral, la organización de los tajos y la dependencia mutua en el trabajo, generando sistemas muy distintos a los propios de la sociedad agrícola circundante. Asimismo aparecieron en época temprana movimientos

\section{Una sociedad industrial al norte de Andalucía}

El distrito minero Linares-La Carolina está situado al norte de Jaén, por lo tanto en la zona más al norte de Andalucía. Su clima es, por esta razón, más extremo que el litoral, con inviernos fríos y veranos extremadamente calurosos y secos. Ocupa un área de $40 \mathrm{~km}$, que se extiende desde Despeñaperros (en Sierra Morena) hacia el sur, con una anchura de este a oeste de $30 \mathrm{~km}$ aproximadamente. La altitud con respecto al nivel del mar está comprendida entre los 300 y los 825 metros.

Incluye territorio perteneciente a ocho municipios: Linares, Bailén, Baños de la Encina, Guarromán, Vilches, Carboneros, La Carolina y Santa Elena. Se divide, portanto, en dos zonas bien diferenciadas. Por un lado, las suaves estribaciones de Sierra Morena situadas en el sureste $y$, por otro lado, la zona montañosa del noroeste.

Podría parecer una tierra inhóspita, pero su riqueza mineral la ha convertido en un lugar de gran valor, cuya explotación se han disputado distintas potencias mundiales a lo largo de la historia y ha sido objeto de diferentes colonizaciones, recibiendo e incorporado a su población emigrantes procedentes de lugares lejanos en todas las épocas históricas.

Otra de las características esenciales de esta comarca es la de haber constituido un enclave industrial de gran importancia, que se ha convertido desde mediados del siglo XIX en una llamativa excepción de la realidad socioeconómica andaluza, situada dentro de un entorno provincial y comarcal casi exclusivamente dedicado a la agricultura.

El enorme desarrollo alcanzado por la minería generó una sociedad con acusadas características industriales, que tuvo que desarrollar y adaptar su crecimiento urbano, mediante planes de ensanche, a las grandes exigencias de mano de obra; una sociedad en la que se establecieron grandes compañías extranjeras y nacionales, que contó con un gran número de industrias auxiliares y entidades bancarias, a la que llegaron con adelanto la red ferroviaria, la electrificación y el tranvía y en la que, en suma, se vivieron con intensidad las grandes convulsiones sociales del siglo XIX.

Y así continuó hasta 1991, cuando la economía del distrito, tras largos e intensos conflictos sociales y laborales, tuvo que encajar el durísimo golpe del cierre de la última mina y el abandono de esta actividad que fue el origen de los primeros asentamientos en la zona. Rápidamente una población que había vivido durante más de siglo y medio los éxitos y fracasos de la minería concentró sus esfuerzos en el desarollo de otras actividades industriales. 


\section{Más de cien inmuebles incoados}

El 16 de octubre de 2006, la Dirección General de Bienes Culturales incoó expediente de protección de sesenta inmuebles del patrimonio minero industrial localizados en el antiguo distrito Linares-La Carolina, con el objetivo de inscribirlos como genérica colectiva en el Catálogo General de Patrimonio Histórico Andaluz, complementando así la incoación realizada en 2003 (resolución de 3 de diciembre, BOJA № 8 de 14 de enero de 2004) de otros sesenta y cinco inmuebles, todos ellos pertenecientes a dicho distrito (ver cuadros $p .76$ y p.81)

La incoación de expedientes de protección del patrimonio minero industrial del antiguo distrito de Linares-La Carolina responde a una de las líneas desarrolladas por el Servicio de Protección del Patrimonio Histórico que consiste en el reconocimiento de los valores culturales que residen en los bienes de esta tipología. Valores de carácter histórico, social, técnico, científico, paisajístico e incluso en algunos casos arqueológico, dado que el conjunto de estos inmuebles es el reflejo de las formas de vida y de trabajo de determinadas identidades colectivas, de unas formas de organización del territorio y de una evolución paisajística propia marcada por la actividad allí desarrollada a lo largo del tiempo.

La concentración histórica de inmuebles relacionados con esta actividad minera que se observa en el antiguo distrito de Linares-La Carolina puede ser una de las mayores de Europa. Los restos, desde edificios a instalaciones complejas compuestas de casas de máquinas de bombeo, extracción, calderas, lavaderos, chimeneas, cabrias, cables aéreos y tolvas, entre otras estructuras, así como la gran variedad de maquinaria empleada para las labores de extracción, tratamiento, transporte, etc., permanecen como testimonio de la tecnología utilizada y son reflejo del complejo mundo desarrollado en la zona.

Además de estas instalaciones especializadas también se encuentran varios pobla dos mineros, algunos de ellos actualmente habitados y cuyas estructuras han sido reformadas para adaptarlas a las funciones que en ellas se realizan, mientras que otros han sido completamente abandonados.

Como ejemplo del primero de los casos tenemos el poblado de Los Guindos, ubicado en los términos de La Carolina y Baños de la Encina. Este inmueble incluye un conjunto de viviendas e instalaciones mineras localizadas en torno a los caminos de acceso a los pozos El Guindo y La Manzana. Las viviendas conservan parte de su tipología original aunque en esencia han sido rehabilitadas para mantenerlas en uso. También encontramos complejos como La Culebrina, en Baños de la Encina, formado por varios edificios mineros entre los que destaca una casa de máquina de bombeo Cornish, una casa de máquinas de extracción y otras de generadores, calde ras y transformación. Del poblado, de reducidas dimensiones, se conservan viviendas de trabajadores e ingenieros. Por otro lado, el ejemplo más claro del segundo de los casos es el del poblado denominado El Sinapismo, en La Carolina, en este momento deshabitado, aunque mantiene el trazado de las calles, así como algunas viviendas e instalaciones industriales.

Toda esta actividad minera y las instalaciones que conlleva conducen a la creación de un paisaje singular que caracteriza e identifica esta comarca diferenciándola de otras. Con el abandono de los establecimientos mineros y el cese de la actividad, que culmina en 1991, año en el que cierra la Compañía de Minas La Cruz, última empresa minera del distrito, aumenta el deterioro de toda esta infraestructura con el consiguiente peligro de desaparición y pérdida de valores y bienes. 
X Paisaje marcado por la actividad minera en la zona de La Carolina / Javier Romero, IAPH

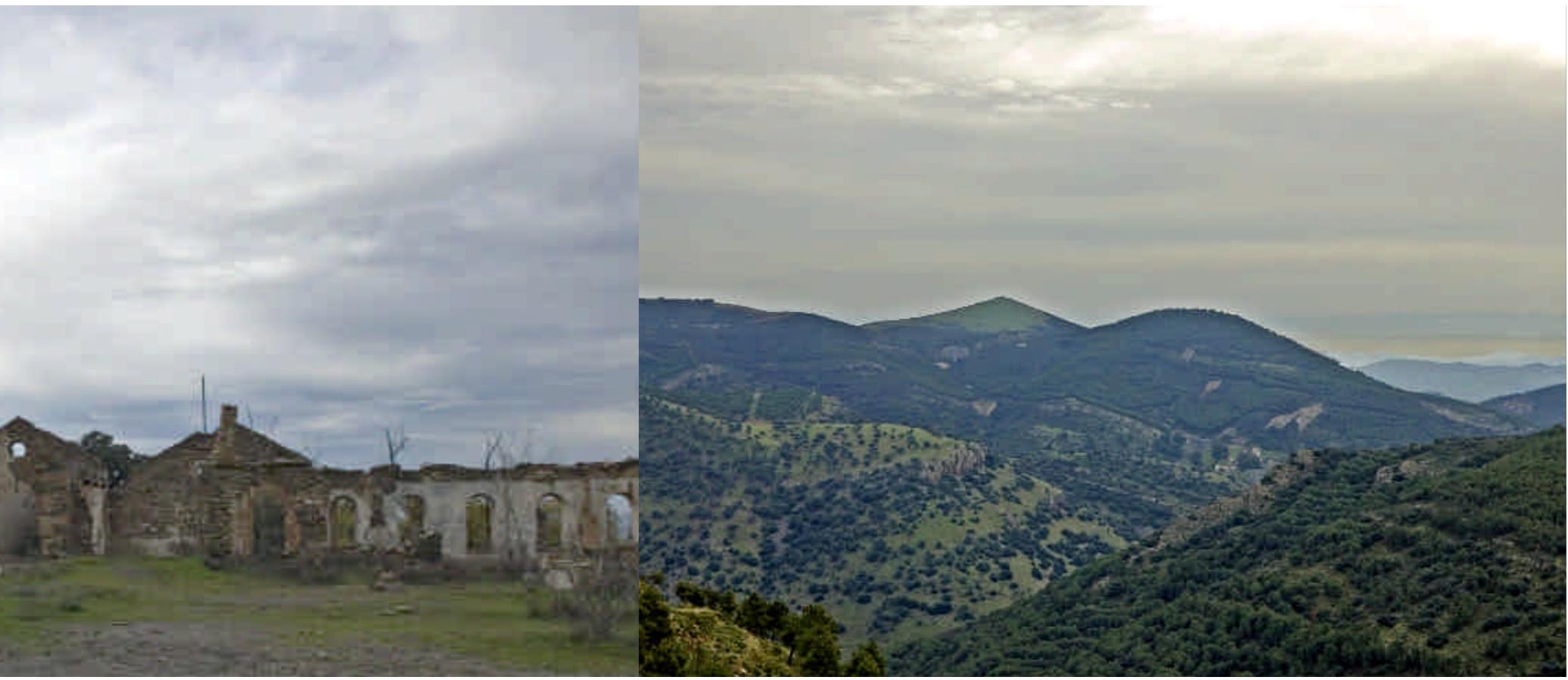

j En España sólo Las Médulas ha sido declarado patrimonio mundial y es representativo de una época de la minería, la romana.

Distintos visitantes, tanto de nuestro país como de diferentes países europeos, han reconocido los enormes valores del legado que la minería nos ha dejado a lo largo del tiempo. Sin embargo, y siendo muy importante el reconocimiento ajeno, es mucho más decisivo para su puesta en valor que la sociedad local lo integre como algo propio, lo defienda como un signo inequívoco de identidad y contribuya en la mayor medida a incrementar sus valores.

Debemos tener claro que conseguir la declaración como patrimonio mundial no es el fin, sino un medio para seguir avanzando, un sello que garantice la calidad del desarrollo cultural y socioeconómico que se vaya realizando. Pero para conseguirla tendremos que demostrar la bondad de las actuaciones previas y el compromiso de continuar trabajando en esta línea, con planes de gestión bien diseñados, con nuevas actuaciones coherentes y con unos objetivos que en sí mismos se proyectan hacia el futuro.

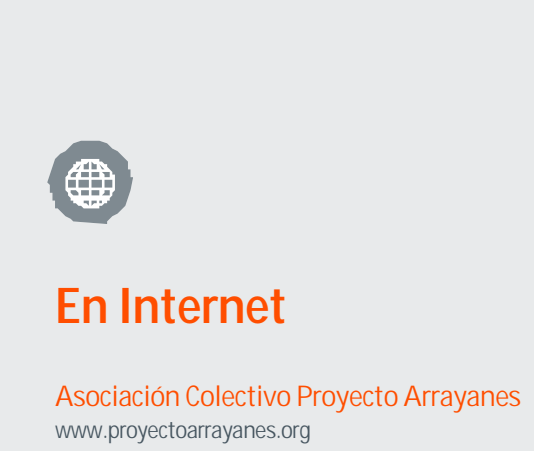

El Proyecto Arrayanes es una propuesta de protección, conservación, recuperación y puesta en valor del patrimonio minero industrial del distrito minero Linares-La Carolina. La página web incluye, además de una referencia a la propia asociación y su proyecto, amplia información sobre el distrito minero Linares-La Carolina desde el punto de vista histórico y patrimonial (incluido el catálogo de los bienes protegidos), las técnicas de extracción minera, el paisaje y el territorio, entre otros aspectos.

\section{Ayuntamiento de Linares}

www.ayuntamientodelinares.org/linares/ruta_minera.htm

www.ayuntamientodelinares.org/linares/minas_en_linares.htm

Se trata de dos accesos, "Ruta minera" y "Minas en Linares", dependientes de la web del Ayuntamiento de Linares y en los que en definitiva se describe una ruta para conocer el paisaje minero de la zona. 
Inmuebles con inscripción genérica colectiva en el Catálogo General de Patrimonio Histórico por Resolución de 3 de diciembre de 2003 (BOJA no 8, 14 enero de 2004)

\begin{tabular}{|c|c|c|}
\hline Denominación & Municipio & Tipol ogías \\
\hline Pozo núm. 1 (Ba-04) & Bailén & Pozos mineros \\
\hline Pozo San José- Matacabras (Ba-05) & Bailén & Pozos mineros \\
\hline Pozo El Correo (Ba-01) & Bailén & Pozos mineros \\
\hline La Esmeralda & Bailén & Edificios industriales \\
\hline Pozo no 3 (Ba-03) & Bailén & Pozos mineros \\
\hline Pozo no 3 (Ba-06) & Bailén & Pozos mineros \\
\hline San Diego (Ba-07) & Bailén & Pozos mineros \\
\hline Pozo no 5 (Ba-08) & Bailén & Pozos mineros \\
\hline San Luis (Gu-01) & Guarromán & Pozos mineros \\
\hline San Cayetano (Gu-02) & Guarromán & Pozos mineros \\
\hline Pozo no 3 (Gu-03) & Guarromán & Pozos mineros \\
\hline San Andrés (Gu-04) & Guarromán & Pozos mineros \\
\hline El Calvario (Li-19) & Linares & Pozos mineros \\
\hline Victoria (Li-01) & Linares & Pozos mineros \\
\hline Santa Annie (Li-02) & Linares & Pozos mineros \\
\hline San Federico (Li-03) & Linares & Pozos mineros \\
\hline Pozo no $0($ Li-20) & Linares & Pozos mineros \\
\hline Lavadero (Li-21) & Linares & Pozos mineros \\
\hline El Fin (Li-04) & Linares & Pozos mineros \\
\hline San José (Li-05) & Linares & Pozos mineros \\
\hline Barings (Li-06) & Linares & Pozos mineros \\
\hline San Adriano (Li-07) & Linares & Pozos mineros \\
\hline San Ignacio (LI-22) & Linares & Pozos mineros \\
\hline Zulueta (Li-23) & Linares & Pozos mineros \\
\hline San Enrique (Li-08) & Linares & Pozos mineros \\
\hline La Unión (Li-24) & Linares & Complejos extractivos \\
\hline Las Cadenas (Li-25) & Linares & Pozos mineros \\
\hline El Chaves (Li-26) & Linares & Pozos mineros \\
\hline San Francisco (Li-09) & Linares & Pozos mineros \\
\hline San Rafael (Li-27) & Linares & Pozos mineros \\
\hline San Judas (Li-10) & Linares & Pozos mineros \\
\hline Juanita (Li-28) & Linares & Pozos mineros \\
\hline Santo Tomás (Li-11) & Linares & Pozos mineros \\
\hline Acosta (Li-12) & Linares & Pozos mineros \\
\hline Restauración (Li-13) & Linares & Pozos mineros \\
\hline San José (Li-14) & Linares & Pozos mineros \\
\hline Magdalena (Li-29) & Linares & Pozos mineros \\
\hline Central Eléctrica (Li-15) & Linares & Centrales eléctricas \\
\hline San Guillermo (Li-16) & Linares & Pozos mineros \\
\hline Pozo Rico (Li-17) & Linares & Pozos mineros \\
\hline San Pablo (Li-30) & Linares & Pozos mineros \\
\hline San Vicente (Li-18) & Linares & Pozos mineros \\
\hline Santa Margarita (Li-31) & Linares & Pozos mineros \\
\hline Rivero (Li-32) & Linares & Pozos mineros \\
\hline Las Animas & Linares & Pozos mineros \\
\hline San Isidro 10 y 20 (Li-34) & Linares & Pozos mineros \\
\hline San Francisco 2a (Li-35) & Linares & Pozos mineros \\
\hline Santa Teresa (Li-36) & Linares & Pozos mineros \\
\hline Los Ministros (Li-37) & Linares & Pozos mineros \\
\hline Pozo B (Li-38) & Linares & Pozos mineros \\
\hline Linarejos (Li-39) & Linares & Pozos mineros \\
\hline Reina $(\mathrm{Li}-40)$ & Linares & Pozos mineros \\
\hline Línea de Ferrocarril Linares Los Sa (Li-Fer-04) & Linares & Edificios del transporte \\
\hline Estación de Madrid (Li-Fer-01) & Linares & Estaciones (Transporte) \\
\hline Fundición La Tortilla (Li-Met-01) & Linares & Fundiciones \\
\hline Torre de Perdigones La Tortilla (Lit-Met-02) & Linares & Torres \\
\hline Chimeneas La Tortilla (Li-Met-03) & Linares & Chimeneas \\
\hline Estación Pozo Ancho (Li-Fer-03) & Linares & Estaciones (Transporte) \\
\hline Chimeneas La Esperanza (Li-Met-04) & Linares & Chimeneas \\
\hline Fundición San Luis (Li-Met-08) & Linares & Fundiciones \\
\hline Chimeneas Fundición A. Hidalgo (Li-Met-05) & Linares & Chimeneas \\
\hline Fundición La Constancia (Li-Met-09) & Linares & Fundiciones \\
\hline Torre Perdigones La Cruz & Linares & Torres \\
\hline Chimenea La Cruz (Li-Met-07) & Linares & Chimeneas \\
\hline
\end{tabular}


Inmuebles con Incoación genérica colectiva en el Catálogo

General de Patrimonio Histórico por Resolución de 16 de octubre de 2006 (BOJA nㅇ219, 13 de noviembre de 2006)

Den o min a ción
Briones
Araceli
Pozo Nuevo
El Mirador
Santo Tomás
El Águila
El Macho
San Guillermo
La Botella
La Culebrina
Los Curas
El Soldado
La Reforma
Monteponi
San Agustín
El Manto
Palazuelos
San Eugenio
La Jaula
Estación de Descarga de Cable
Aquisgrana
Lavadero de Aquisgrana
Pozo Federico
Poblado El Sinapismo
Torre de Perdigones I
Torre de Perdigones II
La Rosa
La Makrina
La Inmediata
San Guillermo
La Española Guindos
Casa de Central en La Urbana
Poblado Los Guindos
Socavón y Lavadero La Manzana
Socavón Santa Juana
San Telmo
San Simón
San Pascual
San Arturo
Pozo Chimenea
San Blas
La Mejicana
Carmen
Herrera
La Memoria
Mistero
María Linarejos
Venus
Lavadero de Adaro
Las Encantadoras
La llusión
Pozo Paquita
Socavón
Santo Rostro
Santa María
Lavadero Vimora
San Gabriel
El Alcázar
La Española
San Miguel

Sal

\section{Municipio \\ Bailén}

Baños de la Encina Baños de la Encina

Baños de la Encina

Baños de la Encina

Baños de la Encina

Baños de la Encina

Baños de la Encina

Baños de la Encina

Baños de la Encina

Baños de la Encina

Baños de la Encina

Baños de la Encina

Baños de la Encina

Baños de la Encina

Baños de la Encina

Carboneros

Carboneros

Carboneros

Carboneros

Carolina, La

Carolina, La

Carolina, La

Carolina, La

Carolina, La

Carolina, La

Carolina, La

Carolina, La

Carolina, La

Carolina, La

Carolina, La

Carolina, La

Carolina, La

Carolina, La

Carolina, La

Carolina, La

Guarromán

Guarromán

Guarromán

Guarromán

Guarromán

Linares

Linares

Linares

Linares

Linares

Linares

Linares

Linares

Linares

Linares

Linares

Linares

Linares

Linares

Linares

Santa Elena

Vilches

Vilches

Vilches

\section{Tipol ogías}

Pozos mineros

Complejos extractivos Complejos extractivos Complejos extractivos Complejos extractivos Complejos extractivos Complejos extractivos Complejos extractivos Complejos extractivos Complejos extractivos Complejos extractivos Complejos extractivos Complejos extractivos Complejos extractivos Pozos mineros

Complejos extractivos Complejos extractivos Complejos extractivos Complejos extractivos Complejos extractivos Complejos extractivos Lavaderos de mineral Pozos mineros

Poblados

Torres

Torres

Complejos extractivos Complejos extractivos Complejos extractivos Complejos extractivos Complejos extractivos Centrales eléctricas Poblados

Lavaderos de mineral Túneles

Complejos extractivos Complejos extractivos Complejos extractivos Complejos extractivos Pozos mineros Complejos extractivos Chimeneas

Complejos extractivos Complejos extractivos Complejos extractivos Almacenes

Complejos extractivos Complejos extractivos Lavaderos de mineral Pozos mineros Complejos extractivos Pozos mineros Túneles

Pozos mineros

Complejos extractivos Lavaderos de mineral Complejos extractivos Complejos extractivos Complejos extractivos Complejos extractivos 


\section{Bienes, paisajes e itinerarios}

\section{Activar un paisaje herido}

Enrique Larive López. Arquitecto

\section{La desactivación productiva de la industria minera dio paso a nuevas estrategias productivas que aceleraron un proceso de alteración}

\section{Un paisaje desactivado}

La imagen de paisaje herido, caótico y futuristaque encontramos en un territorio localizado al norte de la provincia de Jaén, en las estribaciones de Sierra Morena, nos permite apreciar la dimensión que debía de poseer este lugar cuando grandes máquinas de bombeo Cornish y Bull, calderas, cabrias y castilletes, fundiciones, lavaderos, líneas de ferrocarril, horadaban el subsuelo y tapizaban la superficie con alineaciones de chimeneas, arquitecturas, balsas y nuevas topografías de escoria y residuos.

Un paisaje, por otro lado, sometido a lo largo de la historia a importantes acciones y trans formaciones antrópicas que han ido depositando un valor cultural denso, diverso y excepcional: lugar estratégico, espacio frontera, paisaje de batallas, paisaje planificado, paisaje de la minería, etc.

La "agresión" sufrida por el territorio desde que la actividad minera emergió hace 3500 años, llegando a su apogeo a mediados del siglo XIX y hasta la segunda década del siglo XX con la llegada de las grandes compañías europeas y la máquina de vapor, comenzó a cicatrizarse cuando ésta cesó a finales del siglo XX. Las arquitecturas, las máquinas abandonadas y los espacios e infraestructuras, testimonios de un proceso productivo, se convirtieron en patrimonio generando un nuevo paisaje complejo, multidimensional, entrópico, de la memoria, lleno de potencias multidireccionales por explorar y que integraba las interpretaciones y las expectativas de grupos sociales, administraciones públicas e individuos.

La desactivación productiva de la industria minera, por el agotamiento de los filones y los intereses geopolíticos y económicos globales, dio paso a nuevas estrategias productivas agresivas sobre las primeras, acelerando un proceso de alteración.

\section{Un paisaje en reclamación}

Hoy día casi podemos hablar de un paisaje roto, fragmentado, primitivo, con ruinas, de un paisaje dormido esperando despertar y volver a mostrar todas sus posibilidades, o de un paisaje contenedor de composiciones "land-art". Es un paisaje en reclamación. ¿Es un paisaje cultural? ¿Es posible su reciclaje? ¿Son paisajes ávidos de intervención?

Teniendo en cuenta que el patrimonio minero se caracteriza por su diversidad, por una 
OBJETOS. ACCIÓN 1

Estudio activo de paisaje a través de la inserción de la "Variante de Linares"

E1. Intervención rotonda de La Tortilla

Ela. Área de acogida y mirador

Elb. Mirador de alineación de La Tortilla

Elc. Balizas de alineación de La Tortilla

E2. Pasador en la cañada real de Guadiel

E2.a. Filtro de percepción en camino

E3. Estructura vegetal direccional

E4. Pasador en camino de siles

\author{
E5. Filtro de percepción en pasador superior \\ E7. Filtro de percepción en Parque de los Aljibes \\ E7.a. Filtro de percepción en camino \\ E8. Pasador y mirador \\ E9. Filtro de percepción en viaducto \\ E9.a. Amontonamiento de estériles \\ E10. Filtro de percepción en pasador superior \\ E11. Pasador en cañada real de Guadiel
}

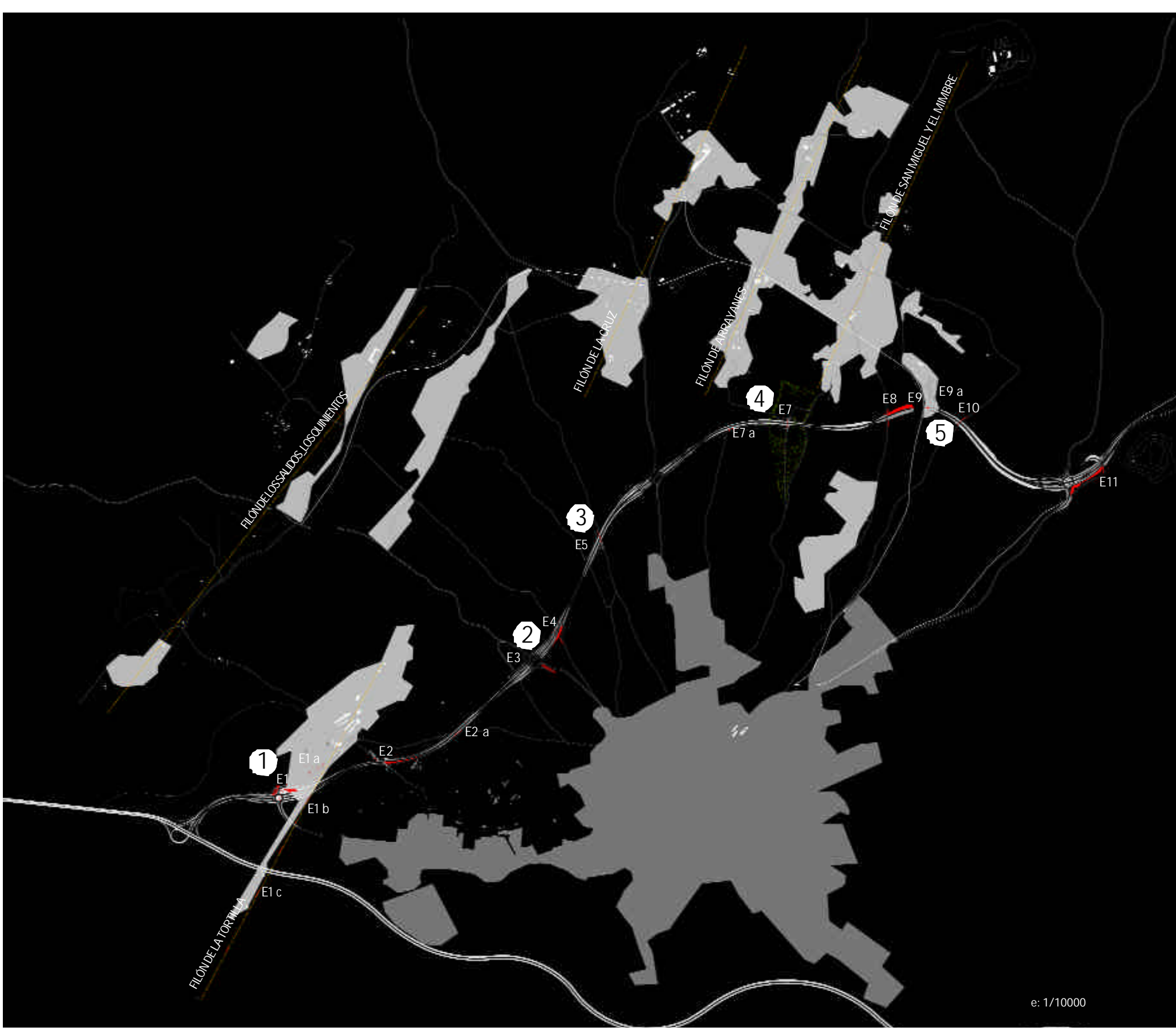




\section{Las nuevas estrategias de acción sobre el paisaje conducen a su reciclaje desde nuevas ópticas que proponen usos, acciones $y$ formas contemporáneas}

intensa memoria social y por un fuerte componente medioambiental, no podemos considerar el paisaje como una adición de elementos puntuales. Debemos ir más allá, tomando las explotaciones mineras como signo identitario del territorio, como una red que ha colonizado y transformado una gran porción de superficie creando un paisaje cultural. No es, por lo tanto, una realidad independiente, autónoma ni aislada, sino que forma parte de un marco territorial amplio, producto de la simbiosis de elementos físicos y antropológicos, que constituyen un activo susceptible de ser recuperado y puesto en valor. Por ello, tenemos que analizarlo en el contexto de su articulación con el territorio al que pertenece, activando la relación entre espacio y tiempo. Hemos de "mirar" el paisaje para encontrar en él las claves que nos permitan comprender la dinámica histórica que ha generado su situación actual, y que pueden desvelarnos cuál debe ser la lógica de intervención.

En el distrito minero Linares-La Carolina nos encontramos con los restos de instalaciones para la explotación y mantenimiento de minas de plomo y plata. Su implantación res pondía a la estructura geológica de los filo nes. Sus arquitecturas eran funcionales sin otra intención. Sus infraestructuras férreas auxiliaban el proceso minero-industrial generando redes de desalojo y abastecimiento. Sus deshechos se amontonaban en grandes topografías artificiales de escoria. Sus galerías esponjaban y registraban el subsuelo con pozos de ventilación y salidas hacia el exterior. Los procesos de manipulación del mineral tatuaban el paisaje de balsas, conductos e ingenios. Sus operarios fundaban colonias residenciales autosuficientes. Las compañías mineras atraían nuevas tecnologías y relaciones internacionales que impulsaban el desarrollo económico y que por otra parte generaban conflictos sociales y medioambientales. Este poso cultural y social, tras años de abandono, mantiene la memoria del lugar. Ese paisaje oculto que impregna las ruinas y los fragmentos, ese paisaje contemplado de alineaciones de chimeneas que nos revelan datos acerca del subsuelo y la configuración geológica de los filones, ese paisaje herido, construido, destruido y parasitado.

Pero, en este vasto territorio minero-industrial, encontramos también gigantescos hitos singulares y relevantes, como el complejo "Fundición La Tortilla". Su cercanía al núcleo urbano de Linares y al nuevo trazado de la variante A-312 la convierten en un lugar estratégico donde localizar un equipamiento híbrido. Un laboratorio de experimentación e interpretación a través de iniciativas contemporáneas, donde poner en marcha un programa de futuro para el distrito minero Linares-La Carolina.

\section{Estrategia de acción}

La planificación territorial desarrollada en la actualidad presenta carencias importantes para abordar el carácter de estos paisajes minero-industriales: ausencia de visión global, falta de relación entre actividad y recursos del territorio, incapacidad para potenciar la integración y la sinergia entre usos, y falta de coordinación de los colectivos implicados. Las nuevas estrategias de acción sobre el paisaje pasan por la apropiación del patrimonio. Un proceso de re-conocimiento, no sólo estudiando su funcionamiento inicial, sino analizando cómo antropizaba el territorio, qué dinámicas generaba, qué usos sociales introducía, etc. Un proceso que ¿necesariamente? ha de conducirnos a su reciclaje.

Reciclaje entendido no desde la creación de lugares de carácter estático y museístico o desde la conservación o reconstrucción bucólica de las formas sin función, que son hoy las minas y fundiciones, sino desde nuevas ópticas que tienen en cuenta la realidad actual, que aceptan las ruinas y que proponen usos, acciones y formas contemporáneas. Se trata de encontrar en estos lugares no sólo una condición humana desde la memoria, sino explorar las potencias multidireccionales con una herramienta activa que trabaje sobre el objeto y su 


\section{Desde la sociedad civil}

El Colectivo Proyecto Arrayanes es una asociación cultural, fundada en 1998, para la valorización del patrimonio minero industrial del distrito Linares-La Carolina. En ella participan antiguos trabajadores de los sectores productivos básicos para Linares (la minería, la industria y el ferrocarril), así como un grupo de profesionales de distintas disciplinas (geólogos, biólogos, ingenieros técnicos de minas, arquitectos técnicos, geógrafos, historiadores, profesores de enseñanza secundaria y de enseñanza universitaria, educadores de museos, etc.).

La asociación sirve de marco de referencia legal para la tutela del anterior Proyecto Arrayanes, iniciativa de la sociedad civil que nació coincidiendo con el cierre de la última mina de plomo en 1991 en esta zona, como propuesta de protección, conservación, recuperación y puesta en valor de este patrimonio.

Como objetivo, persiguen el reconocimiento popular de un patrimonio que consideran parte importante de unas señas de identidad que contribuyen al reforzamiento de la cohesión social.

Han participado también en la elaboración de la documentación técnica para la inscripción en el Catálogo General del Patrimonio Histórico Andaluz de los diferentes bienes inmuebles relacionados con el patrimonio minero de este distrito (resoluciones del 3 de diciembre de 2003 y 16 de octubre de 2006). Actualmente están en proceso de preparación del expediente para la presentación del distrito minero como Patrimonio Mundial de la UNESCO.

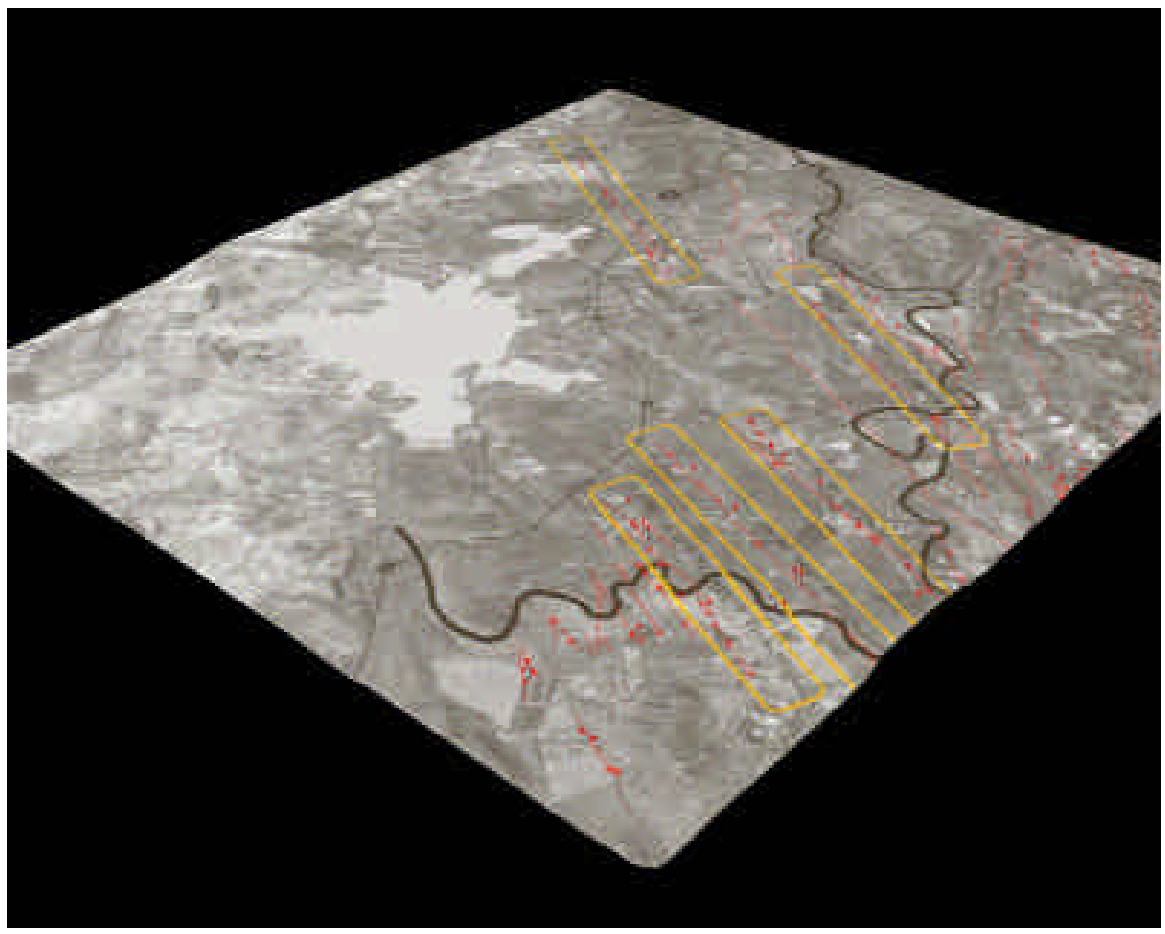

Ricardo Muñoz Vera 
X Arquitecturas en la Fundición La Tortilla ( Linares) / Enrique Larive López
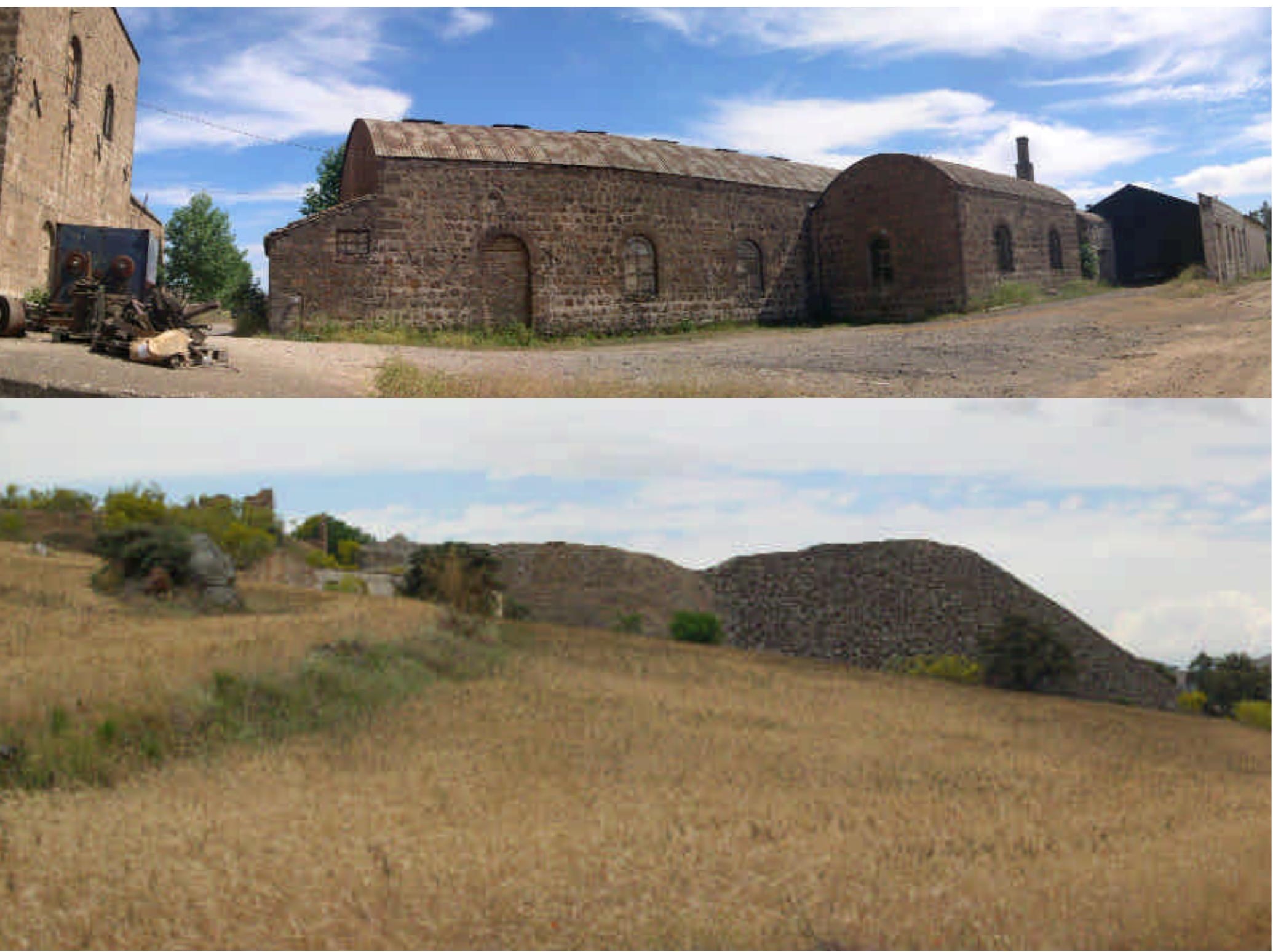

W Amontonamientos de estériles. Filón de La Cruz (Linares) / EnriQue Larive López 
X Línea férrea Linares-Los Salidos / Enrique Larive López

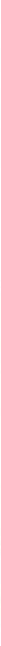




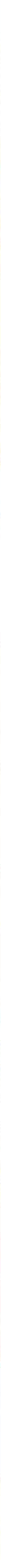

W Estudio activo de paisaje. Estrategia de acción o1: Laboratorio de Arte-Paisaje / EnRIQUE LARIVE López 
contexto. Es necesario aplicar una estrategia trans-disciplinar (arquitecto, artista, ecólogo, urbanista, geógrafo, antropólogo, arqueólogo, historiador, economista...) y trabajar con referencias culturales y artísticas contemporáneas y flujos de comunicación visual, digital, oral e interactiva.

El objetivo genérico de la intervención podría identificarse como la definición de un modelo de integración territorial en el que articular una relación intensa entre el "paisaje cultural", el individuo y la acción. El desarrollo de una "cultura de hacer paisaje" inmersa en las nuevas redes de comunicación entre colectivos e individuos y que ofrezca un nuevo soporte para establecer las relaciones entre patrimonio, contexto y cultura contemporánea. Para ello debemos establecer articulaciones, uniones, gradientes funcionales y lugares ávidos de intervención. Crear una necesidad de experimentar, tanto en el campo profesional como amateur, implicando al público y dando la oportunidad al arte en el territorio.

Este sistema se ordena desde tres líneas o inquietudes: naturaleza, memoria antrópica y cultura contemporánea. A través de un programa que coordine los trabajos de documentación, investigación y acción se incorporan los mecanismos de gestión pública y de concertación social que nos permiten abordar los conflictos de expectativas en la evolución de paisaje del distrito minero Linares-La Carolina.

Las acciones desarrolladas tienen como finalidad la reactivación a través de propuestas contemporáneas de los registros del paisaje cultural: herido, oculto y contemplado.

Un paisaje herido fruto de los procesos de transformación y antropización física del espacio, resultado de las acciones de excavar, horadar, extraer, amontonar, lavar, fundir, transportar, contaminar y producir. Un paisaje oculto, de la memoria, conceptual, producto de un entramado de aspectos sociales, políticos, económicos, tecnológicos y geológicos en continua evolución, fruto de ideas y pensamientos. Un paisaje contemplado que nos conduce a los aspectos visibles, referenciables, simbólicos, objetivos y subjetivos, lleno de espacialidad y temporalidad, evocador como las composiciones residuales de arquitecturas e ingenios mineros en ruinas, los materiales, las texturas naturales y artificiales, el color, etc.

La intervención debe responder a las necesidades contemporáneas de variabilidad, comunicación y acción. La interacción con el medio nos demanda un conjunto de herramientas y usos, de medidas y materiales.

La estrategia de acción, por lo tanto, debe articularse a través de un proyecto activo de paisaje de metodología más global que la puramente urbanística o arquitectónica. Un proyecto que permita acercar las dos realidades, la inactiva y la emergente, tomando como herramientas el patrimonio minero y su contexto, poniendo en el centro del debate la necesidad de contar con los usuarios. Pero no hemos de olvidar que el paisaje es un hecho dinámico, en evolución. Este movimiento hemos de incorporarlo a la acción, generando escenarios, contenidos y proyectos, proponiendo usos novedosos y actividades desde perspectivas contemporáneas que lo hagan atractivo.

Finalmente, debemos establecer las bases y elaborar las primeras propuestas de una red de paisajes minero-industriales en Andalucía, conectadas a otras redes nacionales e internacionales. Se propone iniciar un mapa del territorio estudiado desde sus cualidades naturales y artificiales, desde su diversidad e individualidad, desde el reconocimiento de los factores que lo hacen identitario de cada lugar, con características y problemas diferenciados. Recoger las variables de relación socioculturales y económicas, los escenarios susceptibles de intervenciones y establecer unidades territoriales y estrategias basadas en la activación de estos paisajes culturales. Este nuevo sistema de información de paisajes minero-industriales descubrirá la necesidad de aproximarse metodológicamente al contexto, utilizando sus contenidos para avanzar hacia una nueva manera de estructurar territorialmente Andalucía.
La activación de estos lugares no ha de centrarse en la memoria, sino en explotar las potencias multidireccionales del objeto y su contexto

\section{Nota bibliográfica}

Toda la bibliografía utilizada para la elaboración de este trabajo se puede encontrar en los siguientes proyectos de investigación:

Estudio activo de paisaje a través de la inserción de la variante de Linares. Equipo: Enrique Larive López, M Victoria Segura Raya, Manuela Gómez Rodríguez, Ricardo Muñoz Vera y Lola López Baena (arquitectos); Juan Antonio García Izquierdo y Paz Baturone Bey, estudiantes de arquitectura. Dirección General de Arquitectura y Vivienda. Consejería de Obras Públicas y Transportes. Junta de Andalucía. 2006

Avance de metodología. Programa de actuación paisajistica en el Distrito Minero Linares-La Carolina. Coordinador: Enrique Larive López. Equipo: M Victoria Segura Raya, Manuela Gómez Rodríguez, Ricardo Muñoz Vera (arquitectos). Colaborador: Francisco de Asís Ruiz Labrador, geógrafo. Dirección General de Arquitectura y Vivienda. Consejería de Obras Públicas y Transportes. Junta de Andalucía. 2006 


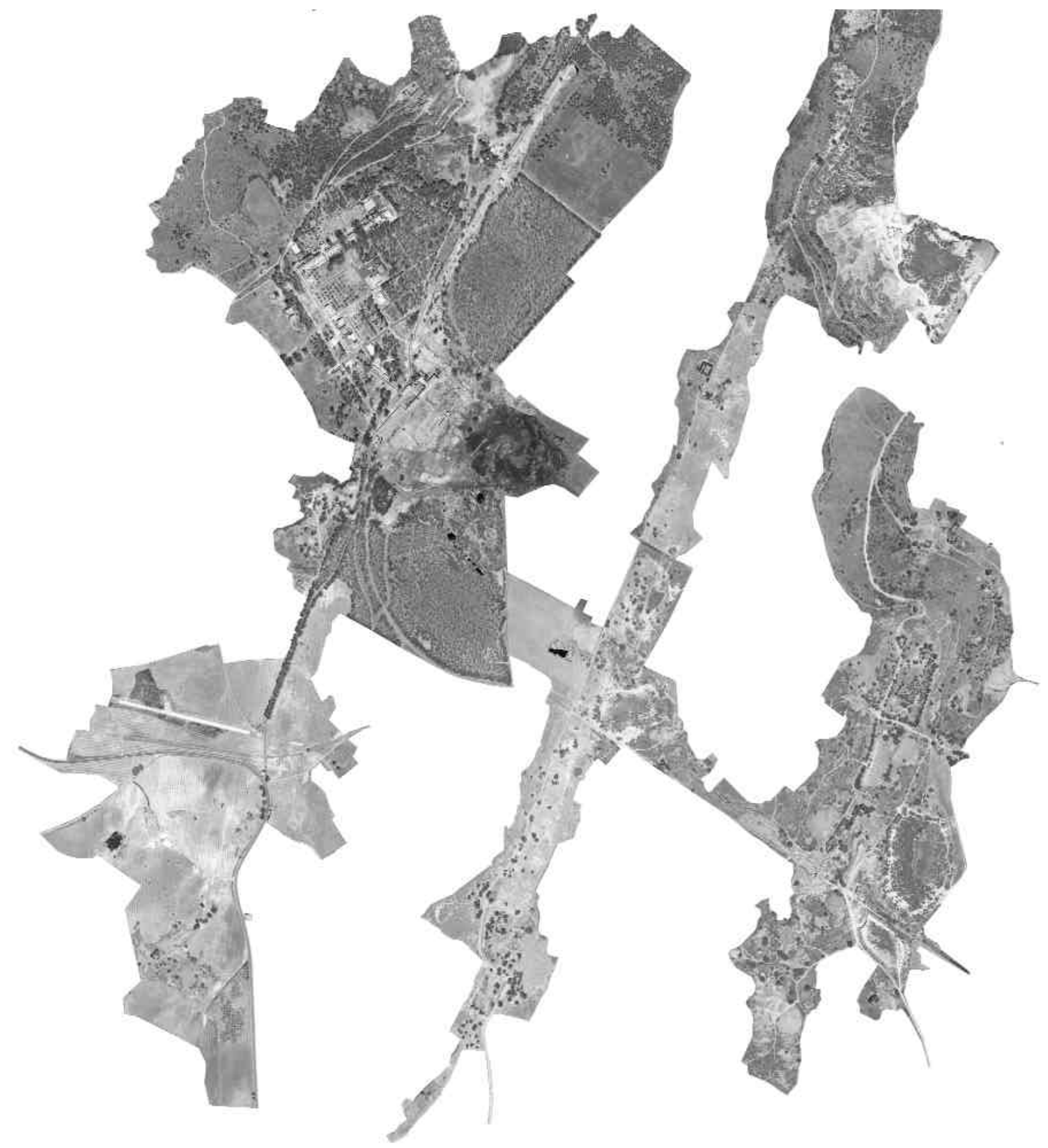

W Estudio activo de paisaje. Paisaje herido. Filones de La Cruz, Arrayanes,

San Miguel y El Mimbre / Enrique Larive López 


\section{Un esfuerzo con proyección internacional}

En el año 1999, el Colectivo Proyecto Arrayanes intensificó de forma muy notable su trabajo para la proyección internacional del patrimonio minero del distrito, coincidiendo con la celebración en Linares de un seminario de trabajo del proyecto MINET, que se había formado para establecer una red europea de emplazamientos mineros. Su incorporación a este proyecto permitió establecer contacto con prestigiosos expertos europeos y con asociaciones y entidades que venían ya realizando actividades y proyectos de puesta en valor. Esto supuso, por un lado, un cambio en la valoración del patrimonio de la zona, confimando quienes la visitaban su gran importancia a nivel mundial. Y, por otro lado, se abrieron nuevas perspectivas sobre cómo desarrollar estos enormes valores y qué estrategias de futuro podían ser más adecuadas.

Otra de las actividades de desarrollo de la red fue la elaboración de un proyecto para el programa europeo Cultura 2000, que fue aprobado en julio de 2004. Su objetivo general era el establecimiento y promoción de una Red Europea de Centros de Patrimonio Minero, abierta a la incorporación de nuevos miembros de toda Europa, para promover prácticas que pudieran servir de referencia o ejemplo para la conservación y el desarrollo sostenible, a través de actividades recíprocas entre los miembros y de acciones colectivas para promover y representar internacionalmente el patrimonio minero común de Europa. Así nació Europamines.

La principal estrategia de trabajo fue la utilización de seminarios de formación, que se celebraron en Comwall (Reino Unido, octubre 2004), Linares (España, diciembre 2004), Vall Chisone (Italia, marzo 2005), Zloty Stok (Polonia, mayo 2005) y Fundao (Portugal, julio 2005). Este proyecto contaba con seis miembros co-organizadores, entre los que se encontraba nuestra asociación, y cuatro miembros asociados de ocho países europeos, y se complementaba con grupos de trabajo sobre temas de educación, comunicaciones, publicaciones, gestión y desarrollo de emplazamientos.

Una vez cubiertos los objetivos del proyecto y terminado el plazo de vigencia, comienza en agosto de 2005 la andadura de la nueva organización y Europamines pasa a constituirse en compañía sin ánimo de lucro, registrada a nivel europeo y con sede en el Reino Unido. Desde el momento de su constitución en el seminario de Polonia, se acordó que el Colectivo Arrayanes detentara la presidencia, decisión que fue ratificada en la Asamblea General en Killhope (Reino Unido) en noviembre de 2005, y en Wroclaw (Polonia, septiembre 2006) se prolongó por otro año esta representación.

Hoy por hoy, Europamines ha consolidado su presencia a nivel europeo, aumentando a diecisiete el número de miembros que ahora proceden de once países (otras cinco asociaciones han manifestado ya su intención de sumarse como potenciales miembros). La relevancia de estos participantes se puede resumir si consideramos que dos miembros han sido ya declarados lugares de Patrimonio Mundial (Rammelsberg y Cornwall) y otro ya ha iniciado su candidatura (Linares).

En cuanto a los resultados, se ha publicado un código de buenas prácticas para la conservación y el desarrollo socioeconómico y cultural de los lugares de patrimonio minero, se han realizado ya tareas de mediación en algunos conflictos relacionados con el patrimonio en distintos lugares del mundo, se mantienen excelentes relaciones con TICaH, con la Organización intemacional de Geoparques y con diversos proyectos de cultura minera, y se ha establecido una marca de calidad para avalar el desarrollo de lugares mineros. Así mismo, se elaboran proyectos de investigación sobre las migraciones asociadas a la expansión de la actividad minera y otros de cooperación intemacional con diversos países latinoamericanos para preservar el patrimonio minero. Por otro lado, la página web (www.europamines.com) se ha mejorado y constituye ya una excelente herramienta de difusión, intercambio entre los miembros y de trabajo en red. 


\section{Desde la sociedad civil}

El Colectivo Proyecto Arrayanes es una asociación cultural, fundada en 1998, para la valorización del patrimonio minero industrial del distrito Linares-La Carolina. En ella participan antiguos trabajadores de los sectores productivos básicos para Linares (la minería, la industria y el ferrocarril), así como un grupo de profesionales de distintas disciplinas (geólogos, biólogos, ingenieros técnicos de minas, arquitectos técnicos, geógrafos, historiadores, profesores de enseñanza secundaria y de enseñanza universitaria, educadores de museos, etc.).

La asociación sirve de marco de referencia legal para la tutela del anterior Proyecto Arrayanes, iniciativa de la sociedad civil que nació coincidiendo con el cierre de la última mina de plomo en 1991 en esta zona, como propuesta de protección, conservación, recuperación y puesta en valor de este patrimonio.

Como objetivo, persiguen el reconocimiento popular de un patrimonio que consideran parte importante de unas señas de identidad que contribuyen al reforzamiento de la cohesión social.

Han participado también en la elaboración de la documentación técnica para la inscripción en el Catálogo General del Patrimonio Histórico Andaluz de los diferentes bienes inmuebles relacionados con el patrimonio minero de este distrito (resoluciones del 3 de diciembre de 2003 y 16 de octubre de 2006). Actualmente están en proceso de preparación del expediente para la presentación del distrito minero como Patrimonio Mundial de la UNESCO.

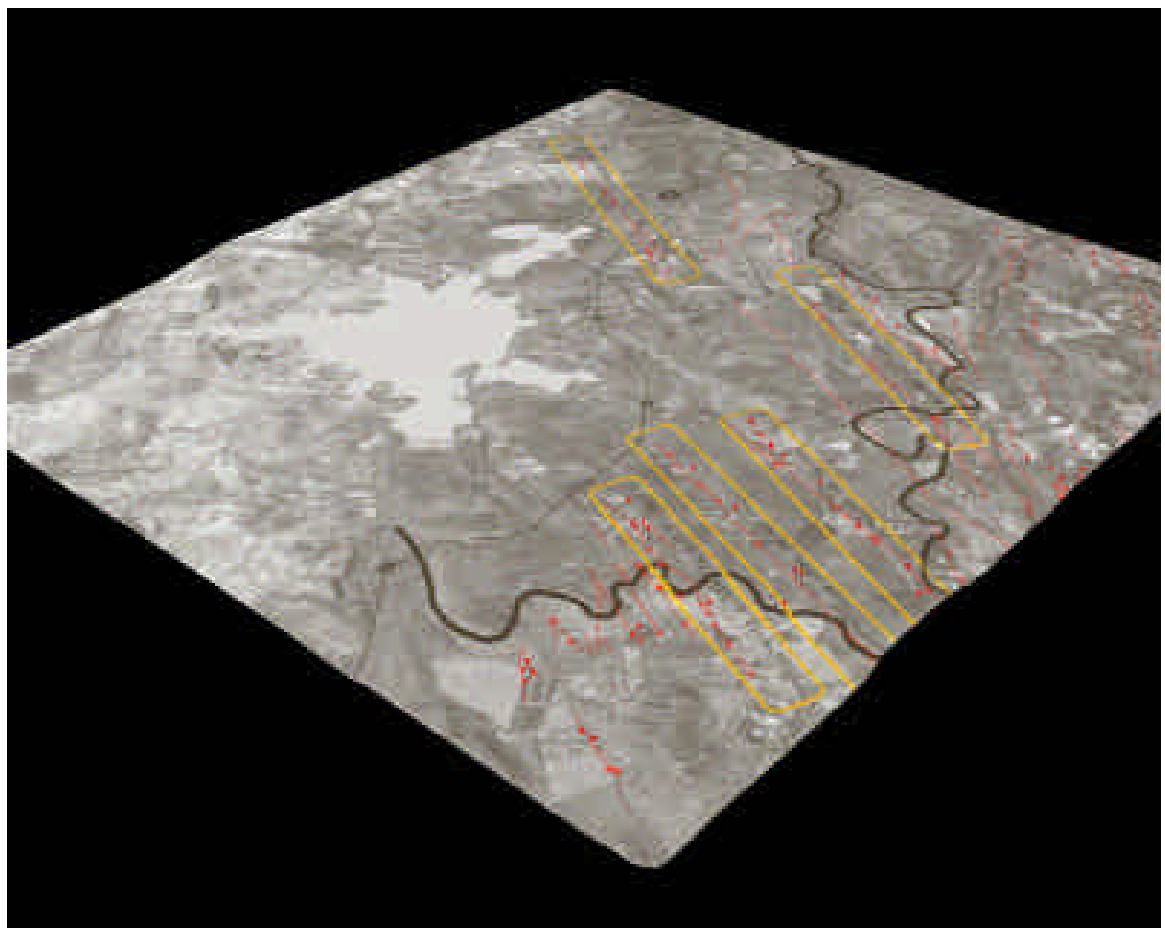

Ricardo Muñoz Vera 


\section{Un esfuerzo con proyección internacional}

En el año 1999, el Colectivo Proyecto Arrayanes intensificó de forma muy notable su trabajo para la proyección internacional del patrimonio minero del distrito, coincidiendo con la celebración en Linares de un seminario de trabajo del proyecto MINET, que se había formado para establecer una red europea de emplazamientos mineros. Su incorporación a este proyecto permitió establecer contacto con prestigiosos expertos europeos y con asociaciones y entidades que venían ya realizando actividades y proyectos de puesta en valor. Esto supuso, por un lado, un cambio en la valoración del patrimonio de la zona, confimando quienes la visitaban su gran importancia a nivel mundial. Y, por otro lado, se abrieron nuevas perspectivas sobre cómo desarrollar estos enormes valores y qué estrategias de futuro podían ser más adecuadas.

Otra de las actividades de desarrollo de la red fue la elaboración de un proyecto para el programa europeo Cultura 2000, que fue aprobado en julio de 2004. Su objetivo general era el establecimiento y promoción de una Red Europea de Centros de Patrimonio Minero, abierta a la incorporación de nuevos miembros de toda Europa, para promover prácticas que pudieran servir de referencia o ejemplo para la conservación y el desarrollo sostenible, a través de actividades recíprocas entre los miembros y de acciones colectivas para promover y representar internacionalmente el patrimonio minero común de Europa. Así nació Europamines.

La principal estrategia de trabajo fue la utilización de seminarios de formación, que se celebraron en Comwall (Reino Unido, octubre 2004), Linares (España, diciembre 2004), Vall Chisone (Italia, marzo 2005), Zloty Stok (Polonia, mayo 2005) y Fundao (Portugal, julio 2005). Este proyecto contaba con seis miembros co-organizadores, entre los que se encontraba nuestra asociación, y cuatro miembros asociados de ocho países europeos, y se complementaba con grupos de trabajo sobre temas de educación, comunicaciones, publicaciones, gestión y desarrollo de emplazamientos.

Una vez cubiertos los objetivos del proyecto y terminado el plazo de vigencia, comienza en agosto de 2005 la andadura de la nueva organización y Europamines pasa a constituirse en compañía sin ánimo de lucro, registrada a nivel europeo y con sede en el Reino Unido. Desde el momento de su constitución en el seminario de Polonia, se acordó que el Colectivo Arrayanes detentara la presidencia, decisión que fue ratificada en la Asamblea General en Killhope (Reino Unido) en noviembre de 2005, y en Wroclaw (Polonia, septiembre 2006) se prolongó por otro año esta representación.

Hoy por hoy, Europamines ha consolidado su presencia a nivel europeo, aumentando a diecisiete el número de miembros que ahora proceden de once países (otras cinco asociaciones han manifestado ya su intención de sumarse como potenciales miembros). La relevancia de estos participantes se puede resumir si consideramos que dos miembros han sido ya declarados lugares de Patrimonio Mundial (Rammelsberg y Cornwall) y otro ya ha iniciado su candidatura (Linares).

En cuanto a los resultados, se ha publicado un código de buenas prácticas para la conservación y el desarrollo socioeconómico y cultural de los lugares de patrimonio minero, se han realizado ya tareas de mediación en algunos conflictos relacionados con el patrimonio en distintos lugares del mundo, se mantienen excelentes relaciones con TICaH, con la Organización intemacional de Geoparques y con diversos proyectos de cultura minera, y se ha establecido una marca de calidad para avalar el desarrollo de lugares mineros. Así mismo, se elaboran proyectos de investigación sobre las migraciones asociadas a la expansión de la actividad minera y otros de cooperación intemacional con diversos países latinoamericanos para preservar el patrimonio minero. Por otro lado, la página web (www.europamines.com) se ha mejorado y constituye ya una excelente herramienta de difusión, intercambio entre los miembros y de trabajo en red. 


\title{
Ruta cultural en el antiguo distrito de Linares-La Carolina
}

\author{
Gema Carrera Díaz, Aniceto Delgado Méndez, Pilar Zafra Costán. Centro de Documentación del IAPH
}

Los bienes

\section{patrimoniales de la}

ruta destacan por ser

espacios de memoria

que deben servir de

nexo de unión entre el

pasado, el presente

y el futuro

Aperaor de la lavá

y échese usté al vaciaero

que viene Venancio Porra

que batirme con él yo quiero
Plantear una ruta cultural por el patrimonio minero del antiguo distrito de Linares-La Carolina resulta sencillo y complicado, como evidentes y complejos pueden ser los sistemas constructivos que perviven en su territorio. Sus chimeneas dibujan el paisaje y delinean la orientación de los filones que se encuentran en el subsuelo, cuyos ricos minerales dieron lugar a tanto ir y venir de pueblos y colectivos especializados en las actividades extractivas, incorporando a su población emigrantes procedentes de lugares lejanos en todas las épocas históricas.

En este territorio encontramos una serie de factores que ayudan a evidenciar la importancia del patrimonio cultural relacionado con la actividad minera de la zona a lo largo de 4000 años de historia ${ }^{1}$. Entre estos fac tores podemos destacar varios que resultan definitorios y otros que contribuyen a entender mejor las características de este "territorio-museo" como patrimonio cultural.

El primero de estos factores es, sin lugar a dudas, la propia importancia de estos edificios industriales. Algunos de ellos, únicos en el mundo y en buen estado de conservación, resultan fundamentales para explicar la configuración actual del territorio y del paisaje originado tras tantos siglos de actividad minera y de la efervescencia del último periodo. A partir de 1850 se dio lo que podemos denominar la eclosión definitiva. La aplicación de tecnología inglesa con la instalación de la primera máquina de vapor para el desagüe supuso una verdadera revo lución, con repercusiones de ámbito internacional. Tanto la actividad extractiva como el tratamiento del mineral han dejado profundas huellas en este paisaje (viario, tipologías constructivas, viviendas y poblados mineros, la propia transformación del suelo), y han influido en las formas de vida y de expresión de estas poblaciones (cantes mineros como las tarantas, fiestas en honor a la patrona de los mineros: Santa Bárbara, determinadas tradiciones gastronómicas, etc.). Estos últimos aún perviven y forman parte de los códigos de comunicación de sus gentes, aunque la actividad minera haya desaparecido hace ya más de una década.

La actividad extractiva en Linares genera la aparición de uno de los contextos urbanos más importantes de Andalucía, una auténtica ciudad minero-industrial que se contrapuso al carácter disperso, reducido y aislado de la mayoría de los enclaves mineros andaluces. Este efecto urbanizador le da a la ciu- 
X Situación del distrito minero Linares-La Carolina en la red de patrimonio minero en Andalucía / Gema Carrera Díaz, David VilLALón

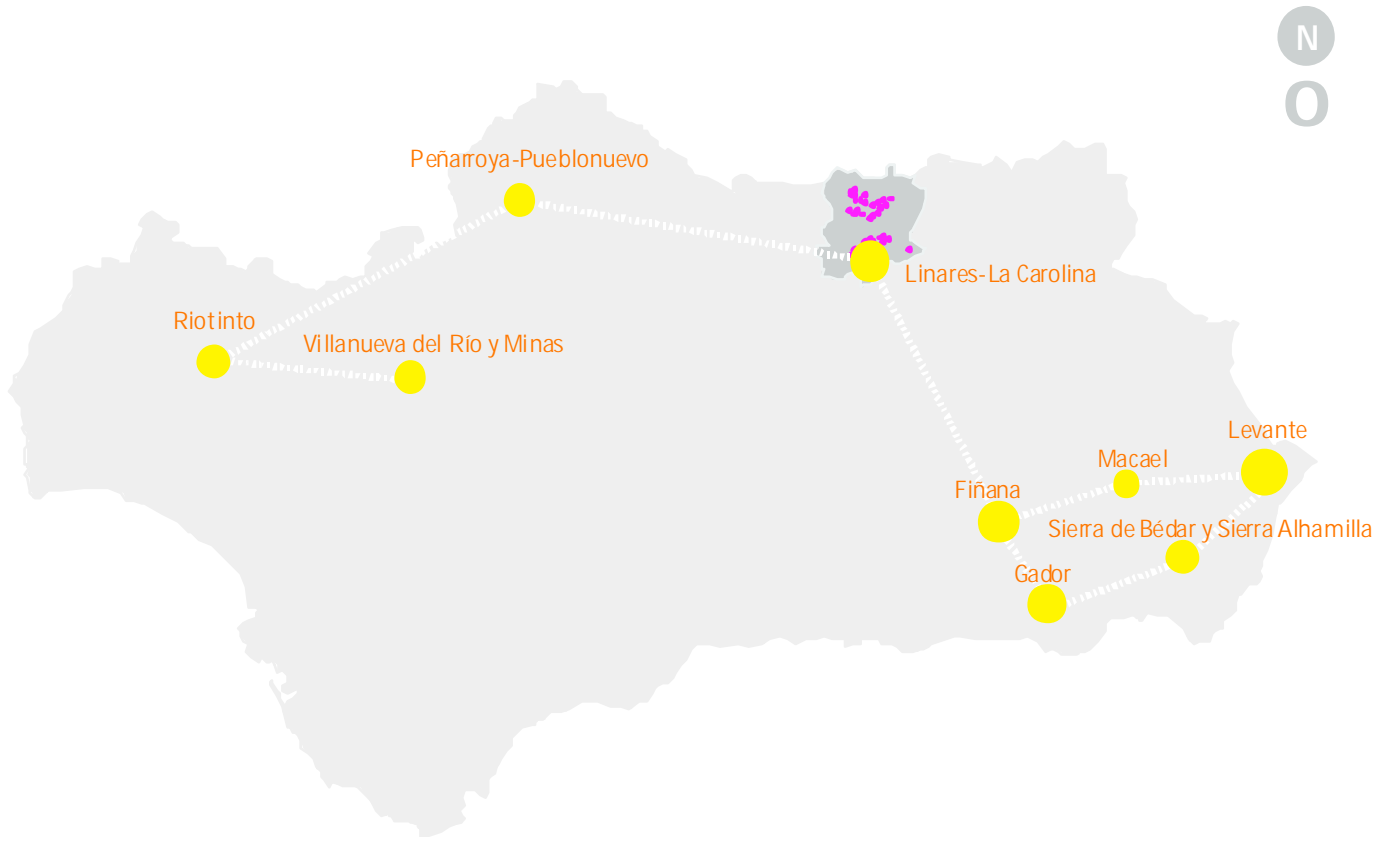

dad de Linares en los siglos XIX y XX el apelativo de "la pequeña Londres de Andalucía".

La contundencia de este legado cultural es de tal calibre que, pocos años después del cierre de la última mina, se ha activado localmente un movimiento asociativo que ha sabido traducir lo que constituían ruinas para la mayor parte de la comarca, en señas de identidad de la misma. Se trata del proyecto Arrayanes², que desde 1998 vienen promoviendo una serie de acciones para la valorización del patrimonio minero industrial en la zona.

Por último, uno de los elementos que más contribuyen a la elaboración y factibilidad de la ruta cultural que se propone para la zona de Linares es el aprovechamiento del trabajo que este colectivo Arrayanes ha realizado junto a la Consejería de Turismo y la Federación Andaluza de Montañismo para la creación de los cincuenta y ocho kilómetros de senderos, señalizados y con paneles interpretativos, que permiten conocer y valorar los restos mineros que hay en el término municipal de Linares, ya que eran los mismos caminos que empleaban los mineros para la realización de sus actividades. Además aprovecharemos la conversión de las líneas férreas desmanteladas que unían los pozos y minas en vías verdes actuales.
X Cabria de mampostería. Pozo de San Vicente. Mina de San Miguel (Linares) Recorrido 1 / JAVIER Romero, IAPH

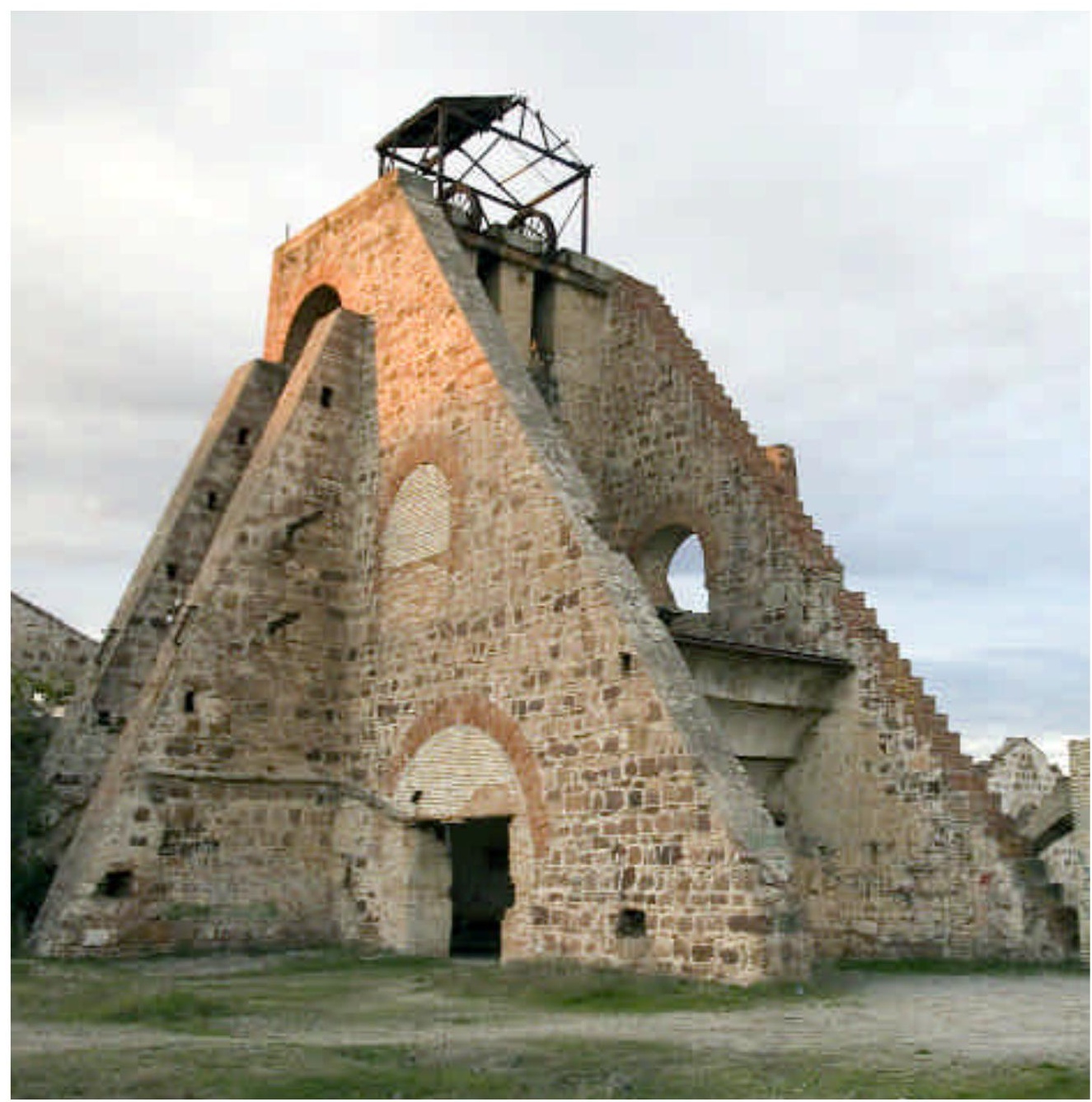



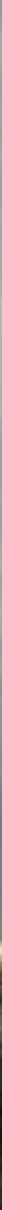

Explotación de Pozo Ancho (Linares).

Recorrido 1 / JAvier Romero, IAPH

Pozo de Santa Annie. Los Lores.

Minas de La Tortilla (Linares)

Recorrido 1 / JAVIER RoMERo, IAPH
Torre de Los Perdigones e instalaciones

anejas. Fundición La Tortilla (Linares).

Recorrido 1 / JAVIER ROMERo, IAPH

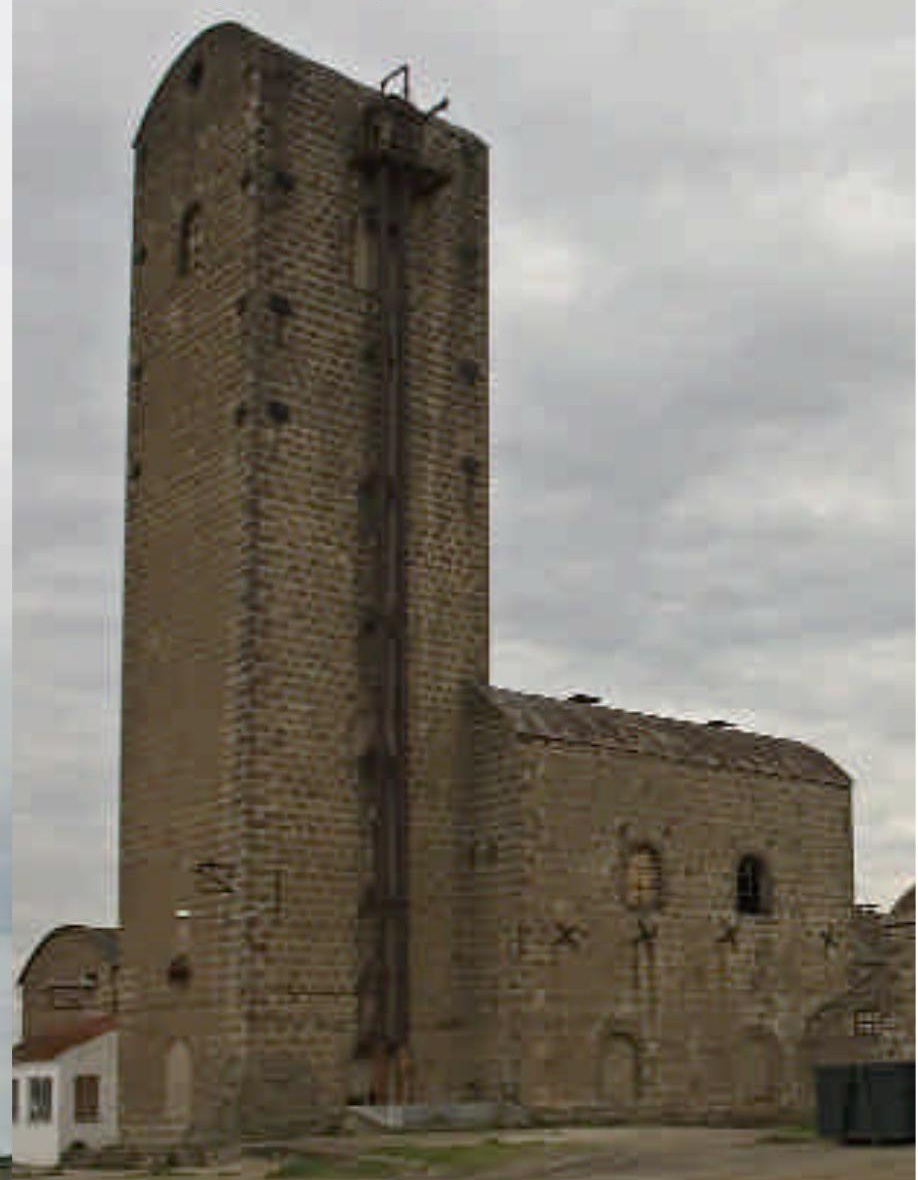


X Recorrido 1 (Linares): Explotaciones de San Miguel-Arrayanes-La Cruz- Pozo Ancho-La Tortilla / Gema Carrera Díaz, David Villalón

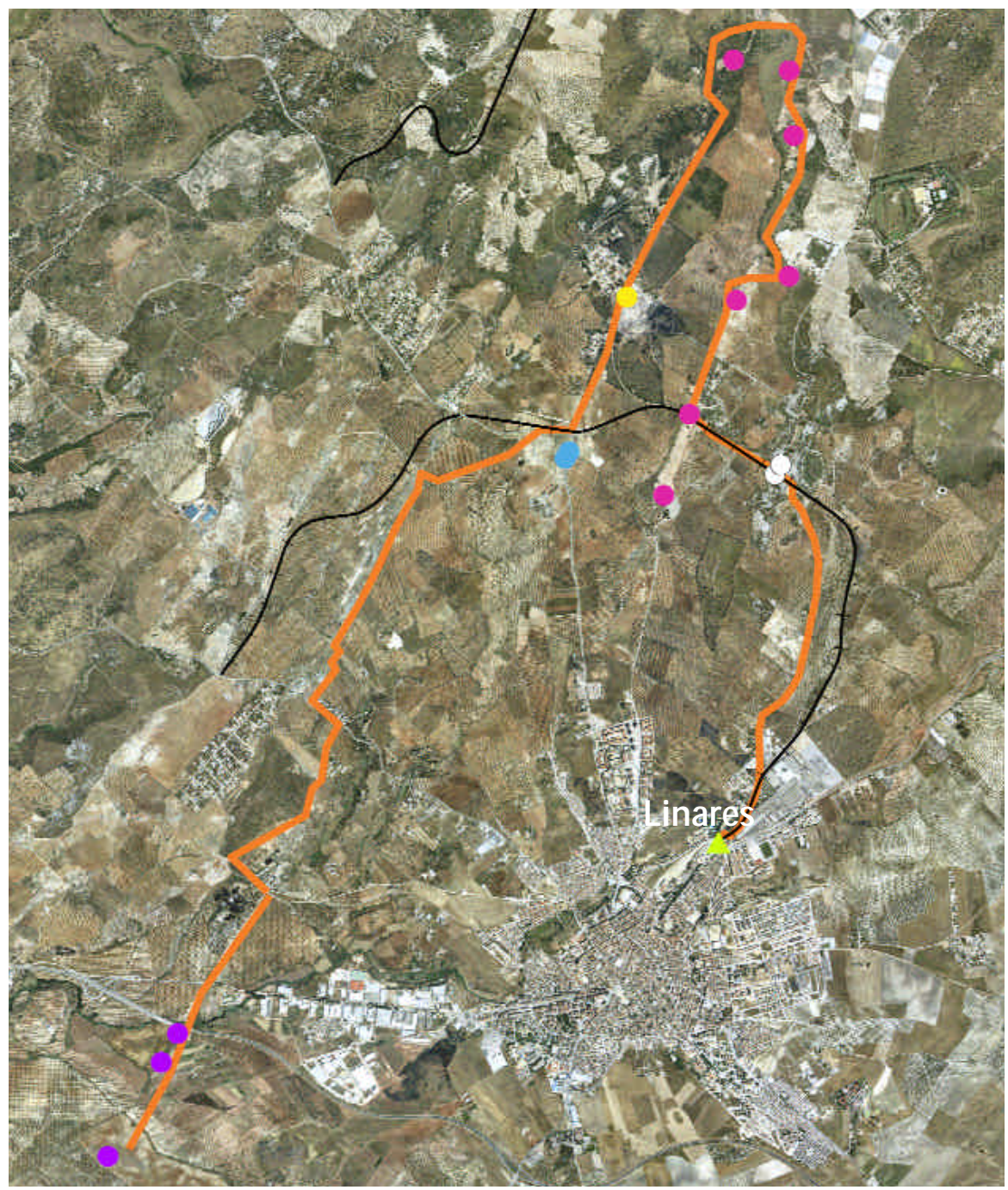

Bienes Inmuebles del Patrimonio Minero

\begin{tabular}{ll} 
Arrayanes \\
Estación de Ferrocarril de Madrid \\
La Cruz \\
La Tortilla-Los Lores \\
Pozo Ancho \\
San Miguel \\
\hline
\end{tabular}

La ruta que se propone en estas líneas (para ubicación geográfica véase p.67) se sitúa en época contemporánea, desde la segunda mitad del siglo XIX hasta los años noventa del siglo XX. Los antecedentes de esta etapa arrancan en Linares, a mediados del siglo XVIII, cuando el Estado se hizo cargo de las minas de Arrayanes, lo que coincidió en el tiempo con la creación de La Carolina como municipio de repoblación, al hilo de la política de nuevas poblaciones impulsadas por Carlos III, con la consiguiente pérdida de su término municipal. Esta nueva localidad tomó el relevo a Linares en la segunda década del siglo XX, experimentando un progresivo declive desde la I Guerra Mundial. Los bienes patrimoniales que apare- cen en la misma no destacan por su singularidad o valores estéticos sino por ser espacios de la memoria que deben servir de nexo de unión entre el pasado, el presente y el futuro.

j Recorrido por la zona de Linares: San Miguel- Arrayanes- La Cruz - Pozo AnchoLa Tortilla

Tomando como referente la red de senderos, creada por el Colectivo Arrayanes (PRA-260), y las antiguas líneas de ferrocarril que conectaban, en un denso entramado, el territorio del distrito, parte este recorrido de la Estación Ferrocarril de Madrid. En pleno corazón de la ciudad, esta estación, futuro Centro de 
X Recorrido 2 (La Carolina-Baños de la Encina): Los Guindos-El Centenillo /

Gema Carrera Díaz, David Villalón

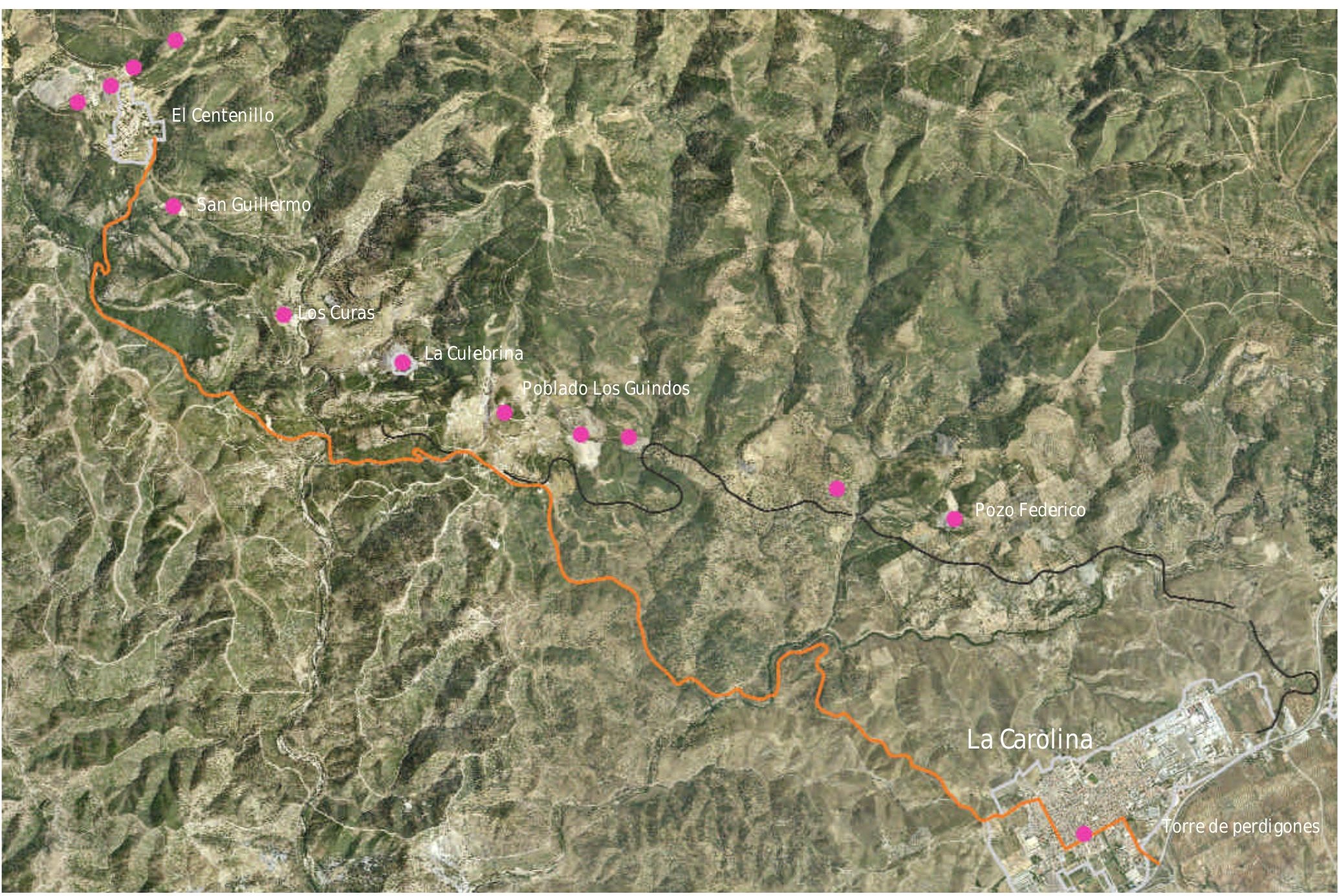

Interpretación de la Minería y la Industria, fue erigida ante la imperiosa necesidad de transportar el plomo con fines comerciales, consti- Patrimonio minero tuyéndose como máximo representante de Recorrido 2. La Carolina - El Centenillo dinamismo que alcanzó el ferrocarril en Linares. Ferrocarril A medida que la ciudad se distancia, comienzan a atisbarse en el paisaje los siguientes hitos del recorrido, entre los que despunta el Pozo de San Vicente. Perteneciente a la mina de San Miguel, con sus más de mil metros de profundidad y su espléndida cabria de mampostería, constituye un ejemplo emblemático de esta tipología constructiva en la zona.

A pocos metros de este complejo se erige 
X Torre de Perdigones. Fundición

La Cruz. Recorrido 1 /

Javier Romero, IAPH
X Pozo de San José. Minas de

Arrayanes. Recorrido $1 /$

JAVier Romero, IAPH

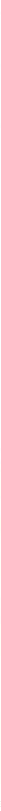

trito Linares-La Carolina, la mayor y más productiva concesión de la zona: Arrayanes. Con más de una decena de pozos en su haber, destacan como los más representativos el Pozo Acosta, que albergaba un conjunto completo de las diferentes casas empleadas en la actividad extractiva y de desagüe; el pozo de San José, ejemplo excepcional de la tipología Cornish inglesa; o el Pozo Zulueta, último del filón de Arrayanes. Esta explotación contó, de igual modo, con una fundición propia, en lo que se conoce como Cerro de San Fausto, un ferrocarril minero para el transporte de material y mineral entre sus numerosos pozos y un moderno lavadero, para preparar, triturar y separar el mineral que contenía plomo de la ganga (estéril). En la actualidad sus restos aún permiten la reproducción del proceso que se seguía con el mineral.

Paralelas a las minas de Arrayanes corren las instalaciones de La Cruz. Su fundición es una de las más vetustas del distrito y la que se mantuvo durante un mayor periodo de tiempo en activo. Junto con su gran chimenea de humos, que llegó a alcanzar los cien metros de altura, los restos más significativos que aún conserva son el pozo La Unión y las instalaciones dedicadas a la elaboración de munición, entre las que destaca su torre de perdigones, con estructura de barras y asentamiento de mampostería y las viviendas de una antigua colonia para empleados.

Pozo Ancho, considerada como una de las explotaciones más emblemáticas de la época después de Arrayanes, se constituyó como uno de los asientos mineros pioneros del distrito ya que albergó una de las primeras bombas de balancín accionadas por vapor de tipología Cornish; los vestigios de sus colosales construcciones así lo atestiguan.

Definido por sus tejados curvos de chapa ondulada, el complejo de La Tortilla anuncia el final de este recorrido. De entre sus instalaciones destaca su fundición, el conjunto arquitectónico-minero mejor conservado de la zona, que aún no siendo visitable es necesario destacar pues conserva en perfectas condiciones una colosal torre de perdigones, de las pocas que quedan en el 
X Iglesia Inmaculada Concepción. Poblado de El Centenillo (Baños de la Encina). Recorrido 2 / JAVIER Romero, IAPH
X El Mirador. Ejemplo paradigmático de Casa Cornish, anexa al poblado minero de El Centenillo (Baños de la Encina). Recorrido $2 /$ JAVIER RoMERo, IAPH

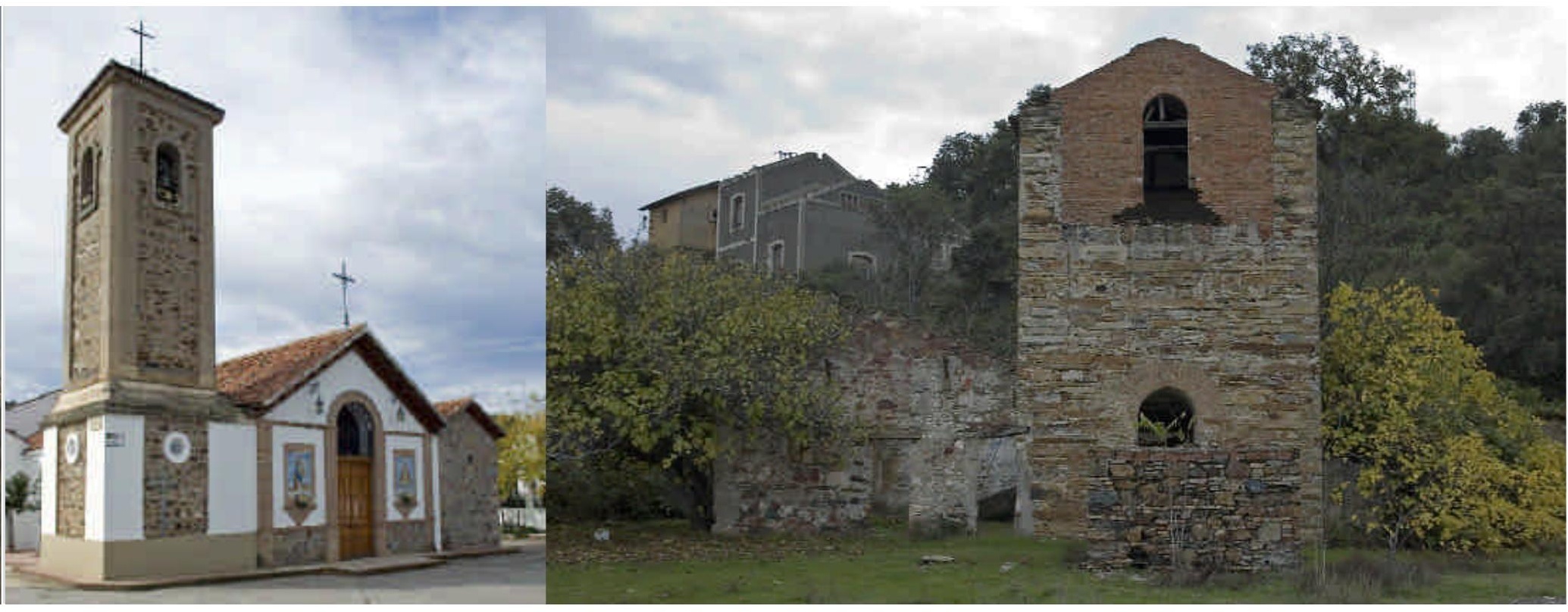

mundo, así como un denso entramado de galerías para el filtrado de otros minerales que evacuan humos en dos chimeneas de considerables proporciones visibles desde todo el campo minero.

Emplazados al final del Filón de La Tortilla, los pozos de Santa Annie y Victoria, conocidos como Los Lores ${ }^{3}$, contribuyeron a alimentar los trabajos de la fundición La Tortilla. Los restos que aún conservan se corresponden fundamentalmente con las casas de máquinas de vapor y las chimeneas, conformando un conjunto característico de la minería linarense, digna heredera y fiel reflejo del paisaje minero de Cornwall, de donde se importa su tecnolo gía y, por consiguiente, su arquitectura.

j Recorrido por la zona de La Carolina: Los Guindos y El Centenillo

Su emplazamiento en Sierra Morena y la abundancia de pizarra en sus filones han condicionado de forma singular la actividad minera de esta zona y, por tanto, los métodos de explotación y los sistemas empleados en la construcción de sus instalaciones.
El recorrido propuesto en estas líneas centra su interés en dos de las compañías más representativas de La Carolina (incluyendo Baños de la Encina) y que marcaron el devenir de la minería en esta zona durante sus años de apogeo, a saber: Los Guindos y El Centenillo. Siguiendo la línea que describe la carretera de El Centenillo, emplazada a la entrada de la localidad de La Carolina, se otean las primeras instalaciones de Los Guindos, una de las más importantes del distrito minero de Linares-La Carolina. Despuntan al inicio del recorrido, el Pozo Federico, que focalizaba las labores de extracción de mineral de la mayor parte del criadero, y La Española Los Guindos cuya cabria aún se sigue imponiendo sobre el paisaje. La empresa Los Guindos disponía de una central eléctrica, la conocida Casa de Central en La Urbana que se empleó para garantizar la energía necesaria para alimentar toda su maquinaria. Junto con el Pozo el Guindo y La Urbana, La Manzana configura la tercera explotación más importante de esta concesión. Entre los restos que aún conserva se adivina el Gran Socavón, que servía de acceso al pozo principal de La
Otras actividades de difusión del Colectivo Arrayanes

j Visitas guiadas

j Ponencias en congresos y cursos

j Ediciones impresas y edición de la revista electrónica La Galena

j Elaboración de un boletín electrónico de noticias

j Exposiciones 


\section{Centros de interpretación para una gestión integral del patrimonio minero}

El punto de partida era la idea de crear una red de centros de interpretación, repartida por el teritorio y conectada mediante una red de caminos y senderos. Estos centros son el eje alrededor del cual se vertebrarán el resto de las actuaciones (ver p. 95) dentro de un proyecto global de actuación. Los temas giran en tomo a:

j El paisaje como elemento esencial que nos permite leer la evolución de la actividad minera y su relación con el medio natural, además de ser el marco en el que resaltan los restos que aún perduran.

j La metalurgia como actividad industrial que completa el proceso de obtención del metal y como industria de importante desarrollo en la comarca minera.

j La explotación minera como conjunto de labores y trabajos interiores y de la tecnología empleada en las instalaciones de las minas.

El Centro de Interpretación del Paisaje Minero

Está ubicado en un muelle de carga de la Estación de Madrid, una nave de piedra de planta rectangular de unos $600 \mathrm{~m}^{2}$ de superficie útil, integrada en el conjunto de la estación, que tiene un gran valor histórico y una situación privilegiada en el centro de la ciudad. El Ayuntamiento de Linares ha rehabilitado el edificio mediante la intervención de la Escuela Taller "Industria y Paisaje", con el asesoramiento del colectivo, contemplando siempre el objetivo de conservar su aspecto y esencia industrial, resaltando los elementos de su estructura y el aspecto exterior de edificio relacionado con el ferrocarril.

El proyecto de contenidos ha sido financiado con alrededor de $110000 €$ del programa "Sierra Morena, tierra minera" de la Consejería de Turismo, y fue encargado por convenio a la asociación, al igual que la documentación necesaria para la licitación de su ejecución. Está diseñado para dar una información relevante para comprender cómo la minería se ha extendido por este territorio, las relaciones que se han establecido entre ella y las poblaciones, y el valor singular que tienen los restos que ha ido dejando a lo largo del tiempo. A su vez, pretende ser el inicio de los posibles itinerarios que se pueden seguir para visitar el territorio musealizado.

Así, la superficie destinada a zona de exposición permanente se compone de una zona de acceso, dedicada al territorio, una sala que explica la génesis y evolución del distrito minero, otra dedicada a la estrecha relación entre la ciudad y las minas, un pasillo en forma de galería longitudinal que describe los trabajo y labores en la mina, y dos salas dedicadas a la interpretación de los restos diseminados por nuestra zona y a la descripción de sus valores.

Para hacer la interpretación más inteligible y amena para todos, se han utilizados medios interactivos como maquetas fijas y móviles, pantallas informativas que permiten a cada visitante profundizar en los aspectos que más hayan llamado su atención y vitrinas que muestran los objetos relacionados con las distintas actividades. Sobresale, por su magnitud, la gran maqueta del territorio del distrito que recibe a los visitantes, de unos 12 m², a escala 1:10.000 y con un sistema de señalización por láser y unas pantallas que muestran información de cada emplazamiento localizado.

El Centro de Interpretación de la Metalurgia

Estará ubicado en la Fundición de La Cruz, que funciona desde 1830, aprovechando las instalaciones de fabricación de munición y las naves de talleres, de espectacular cubierta metálica con detalles modernistas, cedidas por sus propietarios al Ayuntamiento de Linares. Una primera fase de actuación, basada también en un anteproyecto realizado por el Colectivo Arrayanes, ha permitido rehabilitar la zona de la Torre de Perdigones y de fabricación de munición.

Está pendiente de ser dotada de contenidos, que ya han sido diseñados para mostrar la interpretación de la fabricación y clasificación de los perdigones, y una descripción de la importancia de la actividad metalúrgica y de las instalaciones de este tipo que quedan en el distrito. Más adelante, se completará con la interpretación del proceso metalúrgico del plomo y con las reproducciones de elementos esenciales en dicho proceso, como los distintos tipos de homos. 
X Esquema de distribución de salas del Centro de Interpretación del Paisaje Minero / Colectivo Proyecto Arrayanes

V Vista general de la nave donde se ubica el Centro de Interpretación del Paisaje Minero / Colectivo Proyecto Arrayanes

U Esquema general de la distribución interior del Centro de Interpretación del Paisaje Minero / Colectivo Proyecto Arrayanes

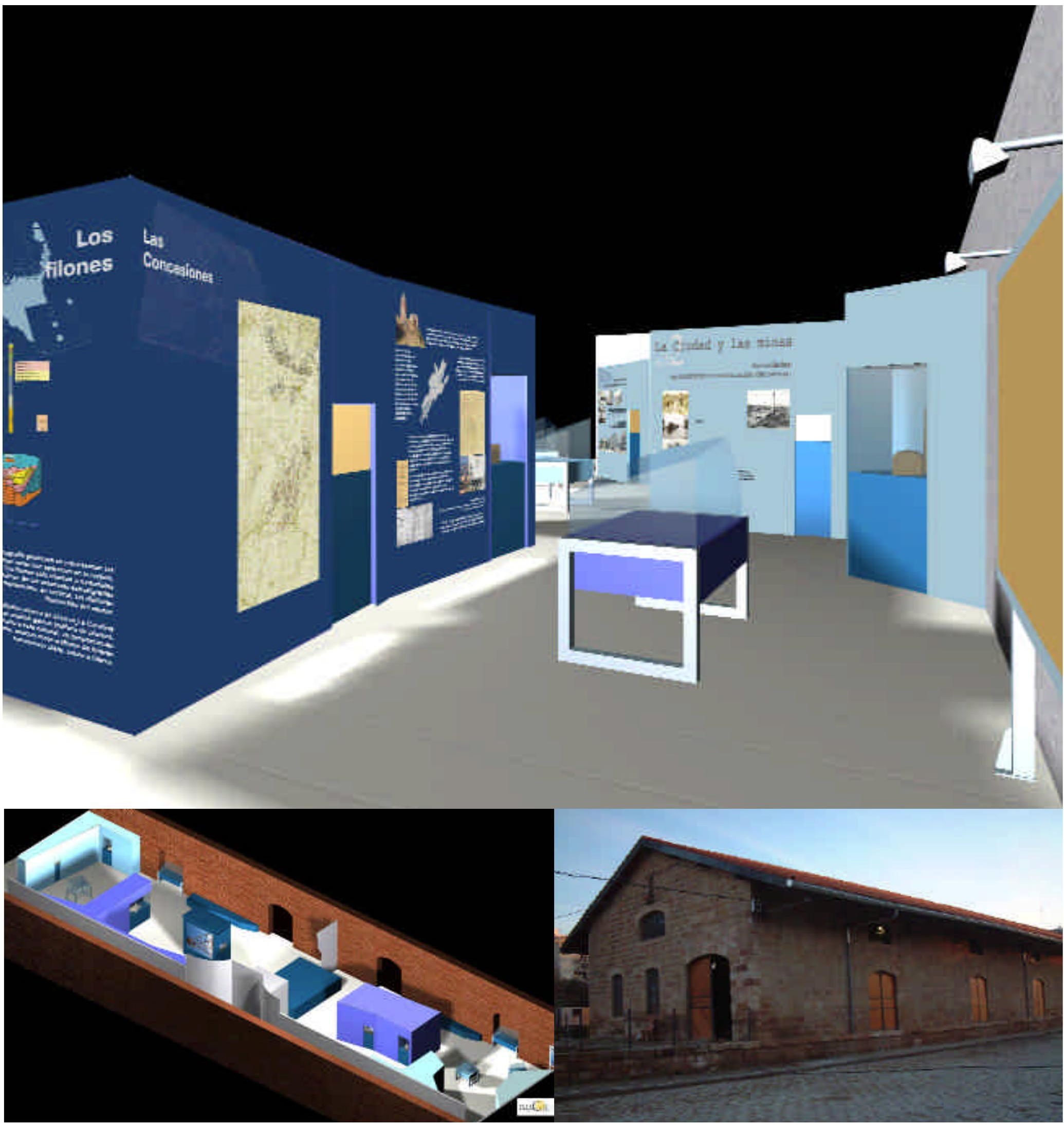




\section{Bibliografía Distrito minero Linares-La Carolina}

BROWN, Kenneth; MORRIS, John; PÉREZ A.; CRITCHLEY, Martin. Interpretación de las ruinas de las casas de máquinas Cornisa. Killhope (Inglaterra) : Europamines, 2005 *

CASADO, C; GÓMEZ, M; MORENO, A ; RAMÍREZ, J.M. Arrayanes. Proyecto de recuperación del patrimonio arqueológico minero industrial . Linares : Taller de Historia, 1991

DOMERGUE, C. En busca del plomo de las minas romanas del distrito Linares-La Carolina (Jaén). En: Patrimonio geológico y minero en el marco del desarrollo sostenible : ponencias y comunicaciones presentadas en el Congreso Internacional sobre Patrimonio Geológico y Minero en el Marco del Desarrollo Sostenible y V Sesión Científica de la Sociedad Española para la Defensa del Patrimonio Geológico y Minero, Escuela Universitaria Politécnica, Linares (Jaén). Madrid : Instituto Geológico y Minero de España, 2000, pp. 61-70*

DUEÑAS MOLINA, J.; GÓMEZ MENA, J.; PÉREZ SÁNCHEZ, A.; RAMÍREZ PLAZA, J.M. Un itinerario por el territorio de Linares (Medio Ambiente y Patrimonio Industrial). Linares : Taller de Ecología de Linares, 1999 *

GUÍA de Linares y su provincia, Jaén, 1880. Ed. facs. Linares : Colegio Oficial de Ingenieros Técnicos de Minas de Linares, 1993

GUTIÉRREZ GUZMÁN, Francisco. Las minas de Linares : apuntes históricos. [S.I.] : Colegio Oficial de Ingenieros Técnicos de Minas de Linares (Jaén, Granada y Málaga), D.L., 1999

GUTIÉRREZ SOLER, Luis María [et al.]. El Centenillo : proyecto de musealización de un paisaje minero en la provincia de Jaén. Anales de Arqueología Cordobesa, ㄲo 11, 2000, pp.73-90*

ITINERARIO minero en el distrito de La Carolina / Itinerario minero en el distrito de Linares (Jaén). En : Patrimonio geológico y minero en el marco del desarrollo sostenible : ponencias y comunicaciones presentadas en el Congreso Internacional sobre Patrimonio Geológico y Minero en el Marco del Desarrollo Sostenible y V Sesión Científica de la Sociedad Española para la Defensa del Patrimonio Geológico y Minero, Escuela Universitaria Politécnica, Linares (Jaén), 20 a 22 de octubre de 2000. Madrid : Instituto Geológico y Minero de España, 2000, pp. 457-464*

La MINERÍA en Linares 1860-1923. Jaén : Diputación Provincial de Jaén y Ayuntamiento de Linares, 1987

MOLERO LÓPEZ-BARAJAS, Emilio; MORENO RIVILLA, Antonio. El paisaje minero industrial de Linares, catalizador de un proceso de desarrollo local. Demófilo. Revista de Cultura Tradicional de Andalucía, № 32, 1999, pp. 261-279 *

MOLINA VEGA, Agustín. Minería y actividades empresariales en el distrito minero LinaresLa Carolina : La Sociedad Minera "el Guindo" : (1899-1920). Jáen : Cámara Oficial de Comercio e Industria de la Provincia de Jaén, 1987

MORENO RIVILLA, Antonio. El distrito minero Linares-La Carolina. ¿El secreto mejor guardado de Europa?. Demófilo : Revista de Cultura tradicional de Andalucía, № 32, 1999, pp. 167-180. *

MORENO RIVILLA, Antonio. Un proyecto para la valorización de los vestigios mineros e industriales de Linares: Arrayanes. En :Preservación de la Arquitectura Industrial en Iberoamérica y España. [Sevilla] : Instituto Andaluz del Patrimonio Histórico; [Granada] : Comares,(Cuadernos; XII), 2001, pp.297-307.*

MUÑOZ DUEÑAS, María Dolores. Importancia del factor tecnológico en el crecimiento económico del distrito minero de Linares 1850-1881. Córdoba : Publicaciones de la Caja de Ahorros de Córdoba,1979, pp. 401-429

PUIDULLÉS, Antonio. La mina de Arrayanes y fábricas de plomos reservados al Gobierno en Linares consideradas en sus dos épocas de administración por la Real Hacienda y en asociación particular. Madrid : Imprenta Nacional, 1838

RUIZ BALLESTEROS, E. (coord.). Cultura minera en Andalucía [Número monográfico]. Demófilo. Revista de cultura tradicional de Andalucía oㅡ 32,2001*

SOLANA RUIZ, José Luis (2006). Decadencia y fin de la minería del plomo, y los últimos mineros en el distrito Linares-La Carolina (Jaén). En : Anuario Andaluz de Etnología 2002 2003. [Sevilla] : Junta de Andalucía, Consejería de Cultura, D.L. 2006* 


\section{Centros de interpretación para una gestión integral del patrimonio minero}

El punto de partida era la idea de crear una red de centros de interpretación, repartida por el teritorio y conectada mediante una red de caminos y senderos. Estos centros son el eje alrededor del cual se vertebrarán el resto de las actuaciones (ver p. 95) dentro de un proyecto global de actuación. Los temas giran en tomo a:

j El paisaje como elemento esencial que nos permite leer la evolución de la actividad minera y su relación con el medio natural, además de ser el marco en el que resaltan los restos que aún perduran.

j La metalurgia como actividad industrial que completa el proceso de obtención del metal y como industria de importante desarrollo en la comarca minera.

j La explotación minera como conjunto de labores y trabajos interiores y de la tecnología empleada en las instalaciones de las minas.

El Centro de Interpretación del Paisaje Minero

Está ubicado en un muelle de carga de la Estación de Madrid, una nave de piedra de planta rectangular de unos $600 \mathrm{~m}^{2}$ de superficie útil, integrada en el conjunto de la estación, que tiene un gran valor histórico y una situación privilegiada en el centro de la ciudad. El Ayuntamiento de Linares ha rehabilitado el edificio mediante la intervención de la Escuela Taller "Industria y Paisaje", con el asesoramiento del colectivo, contemplando siempre el objetivo de conservar su aspecto y esencia industrial, resaltando los elementos de su estructura y el aspecto exterior de edificio relacionado con el ferrocarril.

El proyecto de contenidos ha sido financiado con alrededor de $110000 €$ del programa "Sierra Morena, tierra minera" de la Consejería de Turismo, y fue encargado por convenio a la asociación, al igual que la documentación necesaria para la licitación de su ejecución. Está diseñado para dar una información relevante para comprender cómo la minería se ha extendido por este territorio, las relaciones que se han establecido entre ella y las poblaciones, y el valor singular que tienen los restos que ha ido dejando a lo largo del tiempo. A su vez, pretende ser el inicio de los posibles itinerarios que se pueden seguir para visitar el territorio musealizado.

Así, la superficie destinada a zona de exposición permanente se compone de una zona de acceso, dedicada al territorio, una sala que explica la génesis y evolución del distrito minero, otra dedicada a la estrecha relación entre la ciudad y las minas, un pasillo en forma de galería longitudinal que describe los trabajo y labores en la mina, y dos salas dedicadas a la interpretación de los restos diseminados por nuestra zona y a la descripción de sus valores.

Para hacer la interpretación más inteligible y amena para todos, se han utilizados medios interactivos como maquetas fijas y móviles, pantallas informativas que permiten a cada visitante profundizar en los aspectos que más hayan llamado su atención y vitrinas que muestran los objetos relacionados con las distintas actividades. Sobresale, por su magnitud, la gran maqueta del territorio del distrito que recibe a los visitantes, de unos 12 m², a escala 1:10.000 y con un sistema de señalización por láser y unas pantallas que muestran información de cada emplazamiento localizado.

El Centro de Interpretación de la Metalurgia

Estará ubicado en la Fundición de La Cruz, que funciona desde 1830, aprovechando las instalaciones de fabricación de munición y las naves de talleres, de espectacular cubierta metálica con detalles modernistas, cedidas por sus propietarios al Ayuntamiento de Linares. Una primera fase de actuación, basada también en un anteproyecto realizado por el Colectivo Arrayanes, ha permitido rehabilitar la zona de la Torre de Perdigones y de fabricación de munición.

Está pendiente de ser dotada de contenidos, que ya han sido diseñados para mostrar la interpretación de la fabricación y clasificación de los perdigones, y una descripción de la importancia de la actividad metalúrgica y de las instalaciones de este tipo que quedan en el distrito. Más adelante, se completará con la interpretación del proceso metalúrgico del plomo y con las reproducciones de elementos esenciales en dicho proceso, como los distintos tipos de homos. 


\section{Bibliografía Distrito minero Linares-La Carolina}

BROWN, Kenneth; MORRIS, John; PÉREZ A.; CRITCHLEY, Martin. Interpretación de las ruinas de las casas de máquinas Cornisa. Killhope (Inglaterra) : Europamines, 2005 *

CASADO, C; GÓMEZ, M; MORENO, A ; RAMÍREZ, J.M. Arrayanes. Proyecto de recuperación del patrimonio arqueológico minero industrial . Linares : Taller de Historia, 1991

DOMERGUE, C. En busca del plomo de las minas romanas del distrito Linares-La Carolina (Jaén). En: Patrimonio geológico y minero en el marco del desarrollo sostenible : ponencias y comunicaciones presentadas en el Congreso Internacional sobre Patrimonio Geológico y Minero en el Marco del Desarrollo Sostenible y V Sesión Científica de la Sociedad Española para la Defensa del Patrimonio Geológico y Minero, Escuela Universitaria Politécnica, Linares (Jaén). Madrid : Instituto Geológico y Minero de España, 2000, pp. 61-70*

DUEÑAS MOLINA, J.; GÓMEZ MENA, J.; PÉREZ SÁNCHEZ, A.; RAMÍREZ PLAZA, J.M. Un itinerario por el territorio de Linares (Medio Ambiente y Patrimonio Industrial). Linares : Taller de Ecología de Linares, 1999 *

GUÍA de Linares y su provincia, Jaén, 1880. Ed. facs. Linares : Colegio Oficial de Ingenieros Técnicos de Minas de Linares, 1993

GUTIÉRREZ GUZMÁN, Francisco. Las minas de Linares : apuntes históricos. [S.I.] : Colegio Oficial de Ingenieros Técnicos de Minas de Linares (Jaén, Granada y Málaga), D.L., 1999

GUTIÉRREZ SOLER, Luis María [et al.]. El Centenillo : proyecto de musealización de un paisaje minero en la provincia de Jaén. Anales de Arqueología Cordobesa, ㄲo 11, 2000, pp.73-90*

ITINERARIO minero en el distrito de La Carolina / Itinerario minero en el distrito de Linares (Jaén). En : Patrimonio geológico y minero en el marco del desarrollo sostenible : ponencias y comunicaciones presentadas en el Congreso Internacional sobre Patrimonio Geológico y Minero en el Marco del Desarrollo Sostenible y V Sesión Científica de la Sociedad Española para la Defensa del Patrimonio Geológico y Minero, Escuela Universitaria Politécnica, Linares (Jaén), 20 a 22 de octubre de 2000. Madrid : Instituto Geológico y Minero de España, 2000, pp. 457-464*

La MINERÍA en Linares 1860-1923. Jaén : Diputación Provincial de Jaén y Ayuntamiento de Linares, 1987

MOLERO LÓPEZ-BARAJAS, Emilio; MORENO RIVILLA, Antonio. El paisaje minero industrial de Linares, catalizador de un proceso de desarrollo local. Demófilo. Revista de Cultura Tradicional de Andalucía, № 32, 1999, pp. 261-279 *

MOLINA VEGA, Agustín. Minería y actividades empresariales en el distrito minero LinaresLa Carolina : La Sociedad Minera "el Guindo" : (1899-1920). Jáen : Cámara Oficial de Comercio e Industria de la Provincia de Jaén, 1987

MORENO RIVILLA, Antonio. El distrito minero Linares-La Carolina. ¿El secreto mejor guardado de Europa?. Demófilo : Revista de Cultura tradicional de Andalucía, № 32, 1999, pp. 167-180. *

MORENO RIVILLA, Antonio. Un proyecto para la valorización de los vestigios mineros e industriales de Linares: Arrayanes. En :Preservación de la Arquitectura Industrial en Iberoamérica y España. [Sevilla] : Instituto Andaluz del Patrimonio Histórico; [Granada] : Comares,(Cuadernos; XII), 2001, pp.297-307.*

MUÑOZ DUEÑAS, María Dolores. Importancia del factor tecnológico en el crecimiento económico del distrito minero de Linares 1850-1881. Córdoba : Publicaciones de la Caja de Ahorros de Córdoba,1979, pp. 401-429

PUIDULLÉS, Antonio. La mina de Arrayanes y fábricas de plomos reservados al Gobierno en Linares consideradas en sus dos épocas de administración por la Real Hacienda y en asociación particular. Madrid : Imprenta Nacional, 1838

RUIZ BALLESTEROS, E. (coord.). Cultura minera en Andalucía [Número monográfico]. Demófilo. Revista de cultura tradicional de Andalucía oㅡ 32,2001*

SOLANA RUIZ, José Luis (2006). Decadencia y fin de la minería del plomo, y los últimos mineros en el distrito Linares-La Carolina (Jaén). En : Anuario Andaluz de Etnología 2002 2003. [Sevilla] : Junta de Andalucía, Consejería de Cultura, D.L. 2006* 